Prepared in Cooperation with the Michigan Department of Environmental Quality

\title{
Atrazine Concentrations in Stream Water and Streambed Sediment Pore Water in the St. Joseph and Galien River Basins, Michigan and Indiana, May 2001 - September 2003
}

Open-File Report 2004-1326 


\section{Atrazine Concentrations in Stream Water and Streambed Sediment Pore Water in the St. Joseph and Galien River Basins, Michigan and Indiana, May 2001-September 2003}

By Joseph W. Duris, Howard W. Reeves, and James L. Kiesler

Prepared in Cooperation with the Michigan Department of Environmental Quality

Open-File Report 2004-1326 


\section{U.S. Department of the Interior \\ Gale A. Norton, Secretary \\ U.S. Geological Survey \\ Charles G. Groat, Director}

U.S. Geological Survey, Reston, Virginia: 2005

For sale by U.S. Geological Survey, Information Services
Box 25286, Denver Federal Center
Denver, CO 80225
For more information about the USGS and its products:
Telephone: 1-888-ASK-USGS
World Wide Web: http://www.usgs.gov/

Any use of trade, product, or firm names in this publication is for descriptive purposes only and does not imply endorsement by the U.S. Government.

Although this report is in the public domain, permission must be secured from the individual copyright owners to reproduce any copyrighted materials contained within this report. 


\section{Contents}

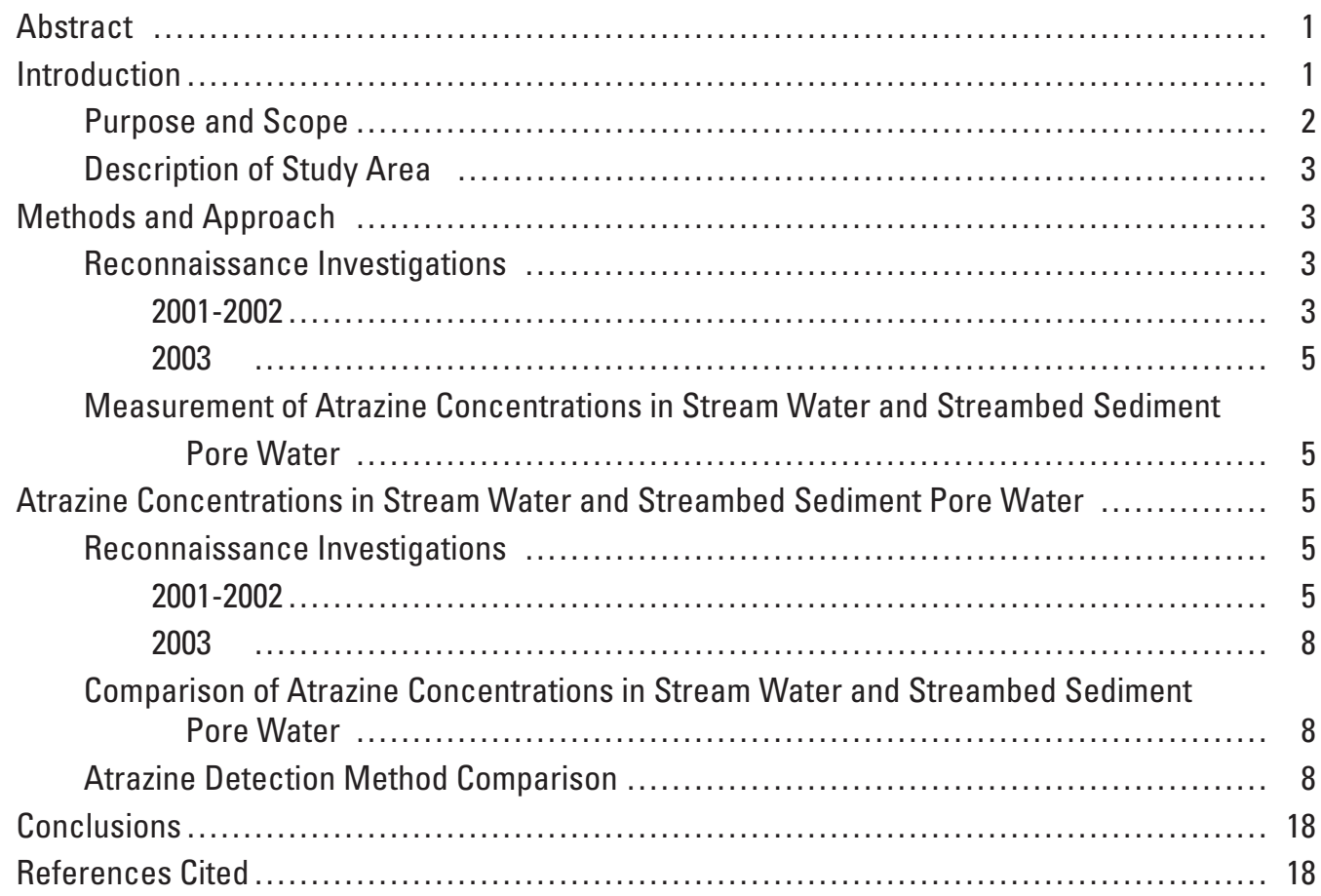

\section{Figures}

1. Map showing surface-water sampling sites in the St. Joseph and

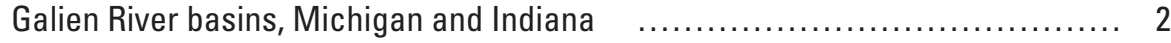

2. Timeline depicting two components of atrazine studies in the St. Joseph and Galien River Basins, Michigan and Indiana ............................... 3

3-6. Maps showing atrazine concentrations in stream water in the St. Joseph and Galien River Basins, Michigan and Indiana:

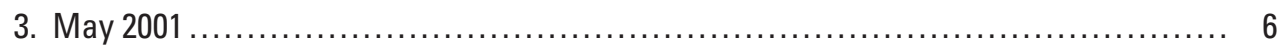

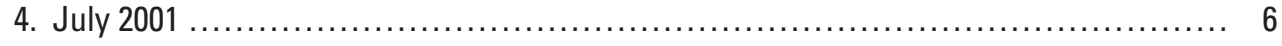

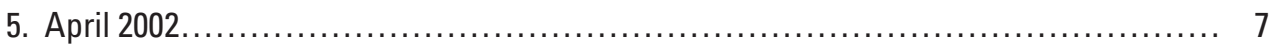

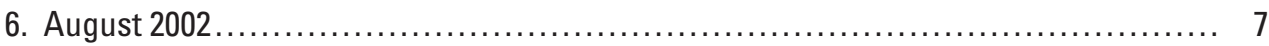

7-10. Maps showing instantaneous loads of atrazine in stream water in the St. Joseph and Galien River Basins, Michigan and Indiana:

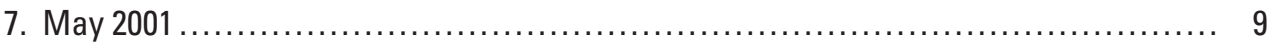

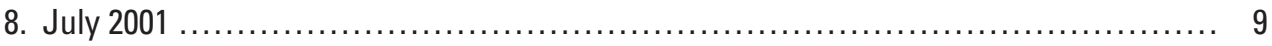

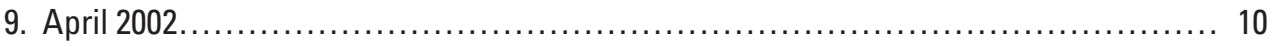

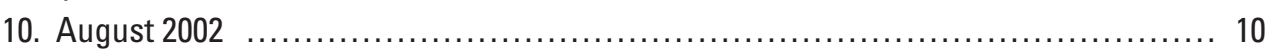


11. Map showing atrazine concentrations in stream water in the St. Joseph and Galien River Basins, Michigan and Indiana, August 2003

12. Map showing atrazine concentrations in stream water in the St. Joseph and Galien River Basins, Michigan and Indiana, September 2003

13. Map showing mean atrazine concentrations in stream water in the St. Joseph and Galien River Basins, Michigan and Indiana, September 2002.

14. Map showing mean atrazine concentrations in streambed sediment pore water in the St. Joseph and Galien River Basins, Michigan and Indiana, September 2002

15. Map showing difference between atrazine concentrations in stream water and streambed sediment pore water in the St. Joseph and Galien River Basins, Michigan and Indiana, September 2002

16. Relation of pore-water to stream-water atrazine concentrations in the St. Joseph and Galien River Basins, Michigan and Indiana, September 2002

\section{Tables}

1. Site location and dates sampled during atrazine study in the St. Joseph and Galien River Basins, Michigan and Indiana

2. Comparison of field ELISA triazine screen and laboratory C-18 chromatography atrazine results

3. Additional water-quality data in the St. Joseph and Galien River Basins, Michigan and Indiana. 14

4. Laboratory herbicide-pesticide screen results in the St. Joseph and Galien River Basins, Michigan and Indiana 


\title{
Atrazine Concentrations in Stream Water and Streambed Sediment Pore Water in the St. Joseph and Galien River Basins, Michigan and Indiana, May 2001 - September 2003
}

\author{
By Joseph W. Duris, Howard W. Reeves, and James L. Kiesler, Jr.
}

\begin{abstract}
The U.S. Geological Survey (USGS) sampled multiple stream sites across the St. Joseph and Galien River Basins to detect and quantify the herbicide atrazine using a field enzyme-linked immunosorbent assay (ELISA) triazine test. In May 2001, July 2001, April 2002, August 2002, August 2003 and September 2003, composite samples were collected across streams at USGS streamflow-gaging stations. Concentrations and instantaneous loading for atrazine sampled in stream water throughout the St. Joseph River and Galien River Basins in Michigan and Indiana ranged from nondetection $(<0.05$ part per billion (ppb)) with an associated load less than 0.001 kilogram per day $(\mathrm{kg} / \mathrm{d})$ to $6 \mathrm{ppb}$ and a maximum load of $10 \mathrm{~kg} / \mathrm{d}$. Atrazine concentrations were highest in May 2001 just after the planting season. The lowest concentration was found in April 2002 just before planting. Atrazine concentrations in streambed-sediment pore water were not spatially connected with atrazine concentrations in stream-water samples. This study showed that atrazine concentrations were elevated from May to July in the St. Joseph and Galien River Basins. At many sites, concentrations exceeded the level that has been shown to feminize frog populations $(0.2 \mathrm{ppb})$. There were 8 sites where concentrations exceeded $0.2 \mathrm{ppb}$ atrazine in May 2001 and July 2001.
\end{abstract}

\section{Introduction}

In 1994-95, the input of atrazine to Lake Michigan from surface-water tributaries was estimated to be 1,600-9,000 kilogram per year, $(\mathrm{kg} / \mathrm{y})$ and this loading was 76 percent of the total loading to the lake (U.S. Environmental Protection Agency, 2000a). Although the St. Joseph River contributed less than 10 percent of the surface-water input to the lake, it contributed the largest load of atrazine, 43 percent of the total, to Lake Michigan in 1994-95 (U. S. Environmental Protection Agency, 2000a).
The Lake Michigan Lakewide Management Plan, or LaMP (U.S. Environmental Protection Agency, 2000b), identified atrazine as an emerging pollutant. Atrazine was registered for use in 1959; between 1987 and 1989, it was the most heavily used herbicide in the United States (U.S. Environmental Protection Agency, 2000b). The half-life for atrazine in soil is estimated to be 60 days (Barbash and Resek, 1996). Atrazine degradation, however, appears to occur primarily under aerobic conditions, and the half-life of atrazine under anoxic or anaerobic conditions, which are expected for ground-water systems, may be much greater than 60 days (Barbash and Resek, 1996).

Prolonged exposure to atrazine and related triazines may cause cardiovascular or reproductive difficulties (U.S. Environmental Protection Agency, 2000b). Atrazine also is considered a potential carcinogen (U.S. Environmental Protection Agency, 2000b). For these reasons, the U.S. Environmental Protection Agency (USEPA) has set the maximum contaminant level (MCL) for atrazine at 3 ppb (U.S. Environmental Protection Agency, 2000b) under the National Primary Drinking Water Regulations of the Safe Drinking Water Act.

Hayes and others (2002) reported laboratory and field studies that implied a feminization of frog populations in the wild when frog larvae were exposed to atrazine. They examined eight field sites and reported that all sites associated with atrazine sales exceeding 0.4 kilogram per square kilometer, $\left(\mathrm{kg} / \mathrm{km}^{2}\right)$ and with waterborne atrazine contamination greater than $0.2 \mathrm{ppb}$ were found to contain males with testicular oocytes. Atrazine sales are used as a surrogate to field loading because field application rates do not have to be reported in all areas. Results and conclusions of the study by Hayes and others (2002) have been questioned (Renner, 2002); nevertheless, atrazine sales in the St. Joseph River Basin greatly exceed the $0.4 \mathrm{~kg} / \mathrm{km}^{2}$ value identified by Hayes and others (2002). An estimate by the U.S. Geological Survey of atrazine application in the basin in 1992 ranges from 3 to more than $10 \mathrm{~kg} / \mathrm{km}^{2}$ atrazine applied (U.S. Geological Survey, 1998). 


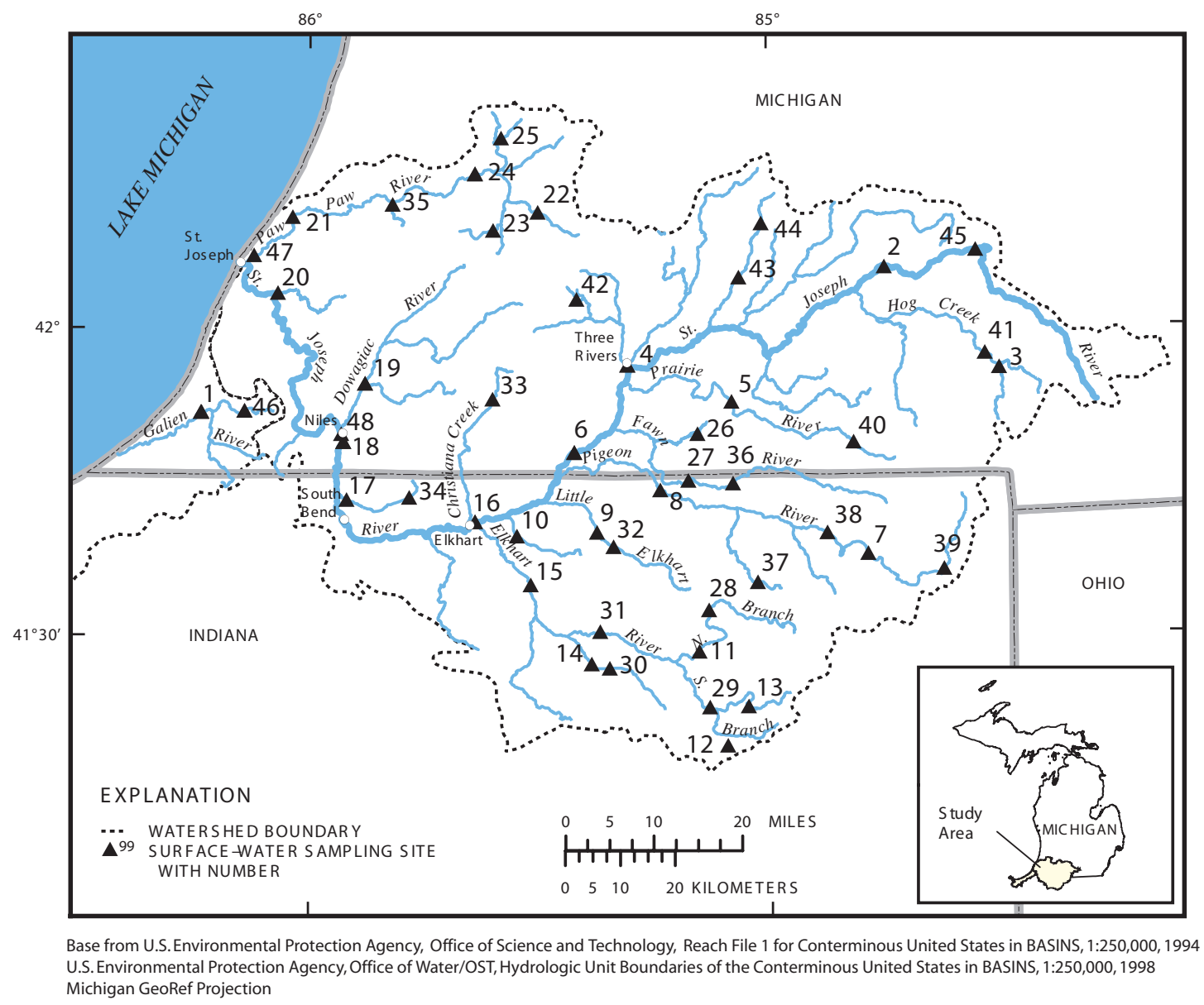

Figure 1. Surface-water sampling sites in the St. Joseph and Galien River Basins, Michigan and Indiana. Site numbers refer to U.S. Geological Survey sites summarized in table 1.

In 2001, the Michigan and Indiana Districts of the USGS began an investigation of ground-water/surface-water interaction in the St. Joseph River Basin (fig. 1) and to test the use of detailed three-dimensional geologic mapping of glacial deposits in the generation of numerical models to study groundwater/surface-water interaction. As a parallel effort, USGS has completed several reconnaissance samplings for atrazine in the St. Joseph River Basin.

The St. Joseph River is a major exporter of atrazine to Lake Michigan (U.S. Environmental Protection Agency, $2000 \mathrm{~b}$ ), and ground water is an important component of the river flow. However, no direct evidence has been collected of the role of ground water in the delivery of atrazine to surface water and to Lake Michigan. An understanding of the mechanisms controlling atrazine transport in the basin is important, as this information may be used by water-resources managers to reduce atrazine loading in Lake Michigan.

\section{Purpose and Scope}

The purpose of this study was to determine whether atrazine was present in stream water within the two basins and to establish whether local high atrazine concentrations could be identified as a first step in understanding the relation of ground water and surface water in atrazine transport. Spatial and temporal variations of atrazine concentrations were examined, as well as methodologies to investigate pore-water/stream-water interactions.

This report summarizes atrazine concentration and load data for samples collected in the St. Joseph River and Galien River Basins from May 2001 to September 2003 as a part of two independent studies. Additional water-quality data collected simultaneously at some of the sampling sites also are presented. 


\section{Description of Study Area}

The St. Joseph River flows through glacially deposited sediments and has a drainage area of $12,100 \mathrm{~km}^{2}$. From 80 to 90 percent of its flow is attributable to ground-water discharge (Holtschlag and Nicholas, 1998). The annual mean daily discharge of the St. Joseph River to Lake Michigan is approximately 100 cubic meters per second, ( $\left.\mathrm{m}^{3} / \mathrm{s}\right)$ (Blumer and others, 2002), whereas the annual mean daily surface runoff to Lake Michigan from all contributing land surfaces is approximately $1200 \mathrm{~m}^{3} / \mathrm{s}$ (Croley and others, 2001). The dynamics of atrazine transport from ground to surface water, however, is unknown. Land use in the basin is dominated by agriculture ( 71 percent) and forest (16 percent), with 5 percent urban, 6 percent wetland, and 2 percent other land-use (USGS, 1992).

The Galien River also flows through glacially deposited sediments and has a drainage area of 332 square $\mathrm{km}^{2}$. Mean daily discharge (calendar year) measured at the Galien River near Sawyer, Mich. site is $1.4 \mathrm{~m}^{3} / \mathrm{sec}$. Land use in the Galien Basin is predominantly agricultural (62 percent) and forest (19 percent), with 4 percent urban, 8 percent wetland and 7 percent other landuse (USGS, 1992).

Atrazine transport to the rivers is likely influenced by local geology, irrigation distribution, rainfall events, and the timing and concentrations of atrazine application. If ground-water transport plays a major role in atrazine distribution, management plans that focus on surface runoff to limit atrazine migration in the environment may not be effective because groundwater could take several years to transport atrazine into surface water (Lindsey and others, 2003). In addition, atrazine load reduction goals for Lake Michigan with targets of five to ten years may not be feasible due to long ground-water transport times.

\section{Methods and Approach}

This study was composed of two components, (fig 2) each designed to address an individual question. First, is atrazine present in the St. Joseph and Galien River Basins and if so at what concentrations? Second, are there any patterns between atrazine concentrations in stream water and streambed pore water? Results of the two components were then combined to assess localized high atrazine concentrations and their distribution throughout the St. Joseph and Galien River Basins. The first component of the study was a reconnaissance investigation designed to assess stream-water atrazine concentrations and, in some locations, stream-water atrazine loads to Lake Michigan. This component took place from May 2001 to September 2003. The second component of this study, which took place in September 2002, was a comparison of atrazine concentrations in streambed pore water and stream water to test methodologies and assess pore-water/ stream-water interaction with regard to atrazine concentration. These studies were then synthesized and the data summarized to assess atrazine concentrations and loads throughout the two basins.

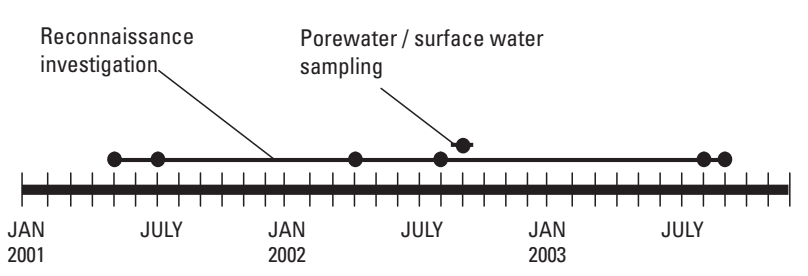

Figure 2. Timeline depicting two components of atrazine study in the St. Joseph and Galien River Basins, Michigan and Indiana. Black dots represent months during which samples were collected.

\section{Reconnaissance Investigation}

Two reconnaissance investigations took place to assess atrazine concentrations in the St. Joseph and Galien River Basins. One study was conducted from 2001-2002 and another was conducted in 2003. There were slightly different methods used in each study as described below.

\section{1-2002}

Atrazine concentrations in stream water were determined from samples collected at 21 sites across the St. Joseph River and Galien River Basins in May and July 2001 and April and August 2002 (fig. 2, table 1). The samples were collected primarily at operating USGS stream gaging stations so that the discharge at the sampling site could be easily obtained and the instantaneous atrazine load determined. The only exceptions were samples collected on Pipestone Creek at River Road near Sodus, Mich. (no streamflow-gaging station) and at Rimmell Branch near Albion, Ind. (streamflow-gaging station discontinued in 2001). One set of samples was collected at the Galien River near Sawyer, Mich. (site 1 on fig. 2, table 1), which is outside of the St. Joseph River Basin, in an effort to compare atrazine concentrations across watersheds.

At each site, grab samples were collected with a galvanized bucket lowered on a rope from the bridge crossing the stream. Grab samples were typically taken at several locations across the stream. The samples were composited in a Teflon bottle, and the composite was then collected into an amber glass bottle and stored on ice in a cooler until analysis. All of the sampling equipment was cleaned and was rinsed with methanol between sampling sites (Wilde and others, 1998). At each site, the sampling equipment and sample bottles were rinsed with the stream water before the sample was collected. A multiparameter meter was used to measure temperature, $\mathrm{pH}$, specific conductance, and dissolved oxygen at the sampling locations across each stream. If the meter indicated a large change in any or all of the four measured parameters across the section, then separate streamwater samples would be collected at that site; however, variations in the four parameters were slight enough across all sections that it was not necessary to collect multiple atrazine samples. The 
Table 1. Site locations and dates sampled during atrazine study, in the St. Joseph and Galien River Basins, Michigan and Indiana

[USGS, U.S. Geological Survey]

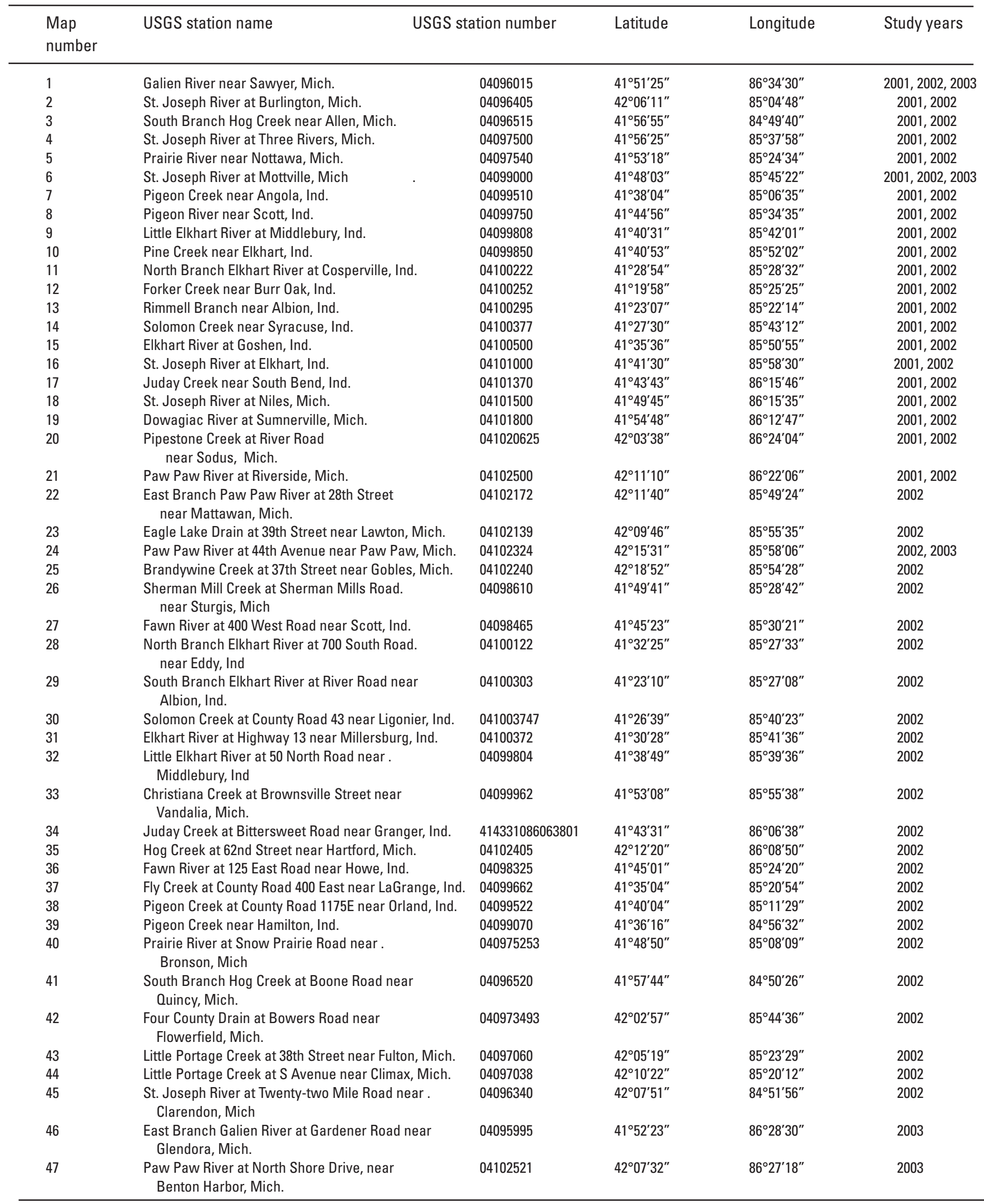


instantaneous gage height was read at each site from a USGS wire-weight gage mounted on a bridge or from the electric tape in the USGS streamflow-gaging station house. The instantaneous gage height was used to determine the instantaneous discharge for the stream from gage height-discharge ratings (Rantz and others, 1982).

Atrazine was measured by means of an ELISA technique (enzyme linked immunosorbent assay). Concentrations were typically measured the day of collection. All samples were stored on ice until analysis (Strategic Diagnostics Inc, 1999). The concentration reported for the ELISA analysis includes atrazine and related triazines (atrazine, propazine, ametryn, prometryn, prometon, desethyl atrazine, terbutryn, terbutylazine, simazine, desisopropyl atrazine, cyanazine, and 2-hydroxy atrazine). In July 2001, two samples were sent to the USGS National Water Quality Laboratory for pesticide screening analysis by means of C-18 solid-phase extraction and capillary-column gas chromatography/mass spectrometry (Zaugg and others, 1995).

Quality-control techniques included field calibration of the multiparameter meter and field checking of the instrument against standards. Field blank samples were used to check sample handling and preparation steps of the analysis, none of which indicated external contamination of samples. Typically, the ELISA analysis was performed in triplicate on all regular and field blank samples.

\section{3}

In August 2003, stream water was collected at four sites in the St. Joseph River Basin and two sites in the Galien River Basin (table 1); many of these sites were ungaged sites. The Galien River sites were also sampled in September 2003. The Galien River sites were used as a spatial reference, but were also chosen in this part of the reconnaissance investigation because they were on a State of Michigan Total Maximum Daily Load (TMDL)-listed reach. Water samples were collected by use of USGS equal-width-integrated (EWI) sampling procedures (Webb and others, 1999). The EWI fractions were collected in a Teflon collection bottle and composited in a high-density polyethylene (HDPE) churn (Webb and others, 1999). Composite samples were then dispensed in sterile HDPE bottles and stored in the dark, on ice, until analysis (no more than 24 hours after sample collection). These samples were sent to the USGS National Water Quality Laboratory for pesticide screening analysis using C-18 solid-phase extraction and capillary-column gas chromatography/mass spectrometry (Zaugg and others, 1995).

\section{Measurement of Atrazine Concentrations in Stream water and Streambed Sediment Pore Water}

In September 2002, pore water and stream water were collected at 28 sites, most of which are ungaged, in the St. Joseph River Basin (table 1). The purpose of this sampling was to test the methods used to extract streambed-sediment pore water and to identify sites for future intensive sampling to quantify ground-water/stream-water exchange. A steel drive-point piezometer was driven into the streambed to a depth of 20 $\mathrm{cm}$. Pore water was extracted from the streambed though the piezometer with low-density polyethylene (LDPE) tubing and a 30-mL syringe connected by Luer-lock fittings (U.S. Geological Survey, 2000). Typically, 3 to $5 \mathrm{~mL}$ of pore water was withdrawn from the streambed and discarded before the sample was collected. The sample was collected into a $1.5-\mathrm{mL}$ amber vial with a screw-top, Teflon-lined cap, and stored on ice until analysis. Several stream- and pore-water samples were collected at each site.

\section{Atrazine Concentrations in Stream Water and Streambed Sediment Pore Water}

Results from the two reconnaissance investigations from 2001-2002 and in 2003 are presented below. They are presented separately to accommodate the slightly different methods used in each study.

\section{Reconnaissance Investigation}

\section{1-2002}

Spatial distributions of stream-water atrazine concentrations from May 2001, July 2001, April 2002, and August 2002 are shown in figures 3 through 6 . Atrazine concentrations in May 2001 were the largest observed in the four sets of samples (fig. 3).

Atrazine is generally applied during or shortly after planting. In the St. Joseph and Galien River Basins, corn is usually planted in late April or early May. The May 2001 samples were collected when many fields were being planted or had just been planted. The maximum atrazine concentration measured was $5.95 \mathrm{ppb}$ at the Galien River near Sawyer, Mich. (site 1).

The only site where the atrazine concentration was below the detection limit of $0.05 \mathrm{ppb}$ during the May 2001 sampling was at the Paw Paw River at Riverside, Mich. (site 21).

Atrazine detections were scattered across the basin, and no strong spatial pattern was evident. Of the 21 sites, 17 had concentrations greater than $0.2 \mathrm{ppb}$, which is the concentration identified by Hayes and others (2002) as leading to feminization of male frogs in the wild.

Atrazine concentrations generally were lower in the July 2001 samples (fig. 4) than in the May 2001 samples. At five sites, concentrations were below the detection limit. The maximum concentration observed was $2 \mathrm{ppb}$ at the Pigeon River near Scott, Ind. (site 8). Samples from nine sites had concentra- 


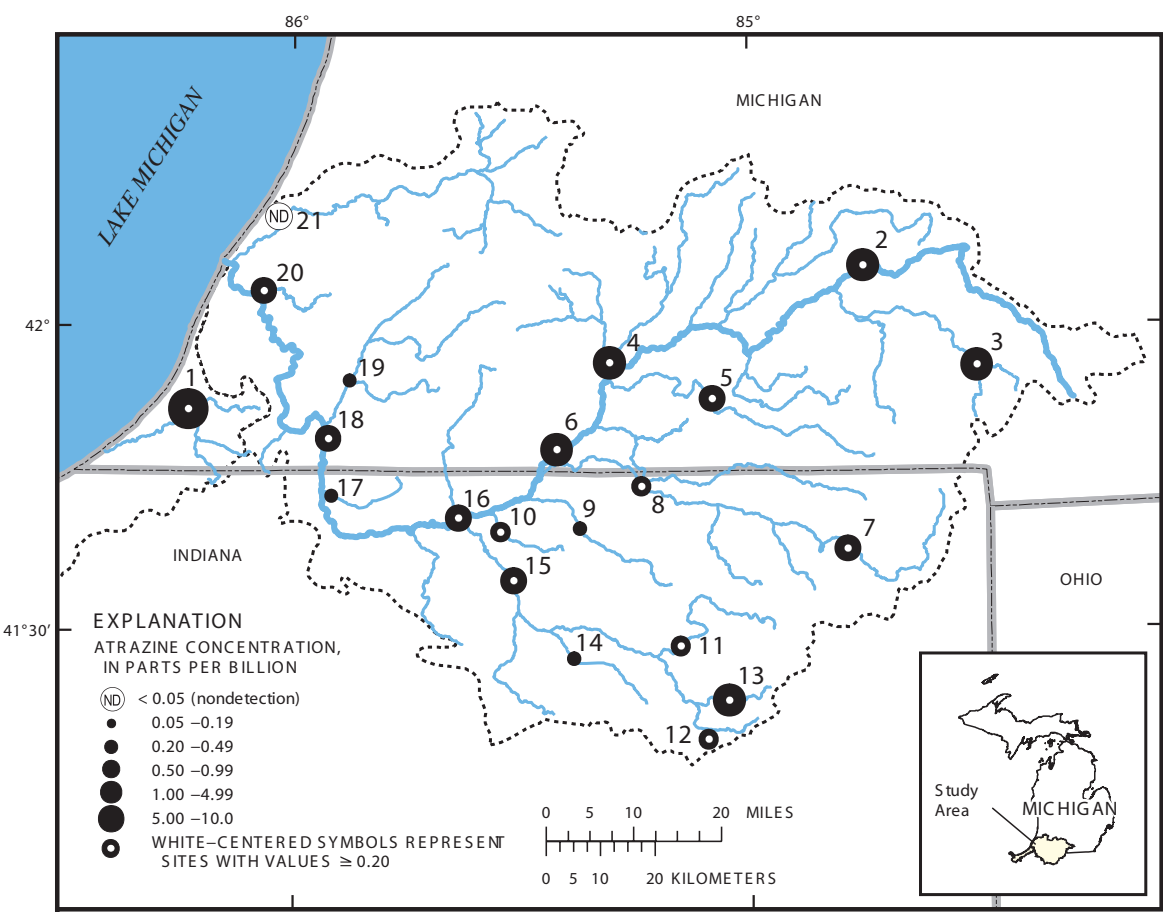

Base from U.S. Environmental Protection Agency, Office of Science and Technology, Reach File 1 for Conterminous United States in BASINS, 1:250,000, 1994 U.S. Environmental Protection Agency, Office of Water/OST, Hydrologic Unit Boundaries of the Conterminous United States in BASINS, 1:250,000, 1998 Michigan GeoRef Projection

Figure 3. Atrazine concentrations in stream water in the St. Joseph and Galien River Basins, Michigan and Indiana, May 2001. White centered symbols represent atrazine concentrations that exceed the amount determined to feminize frog populations.

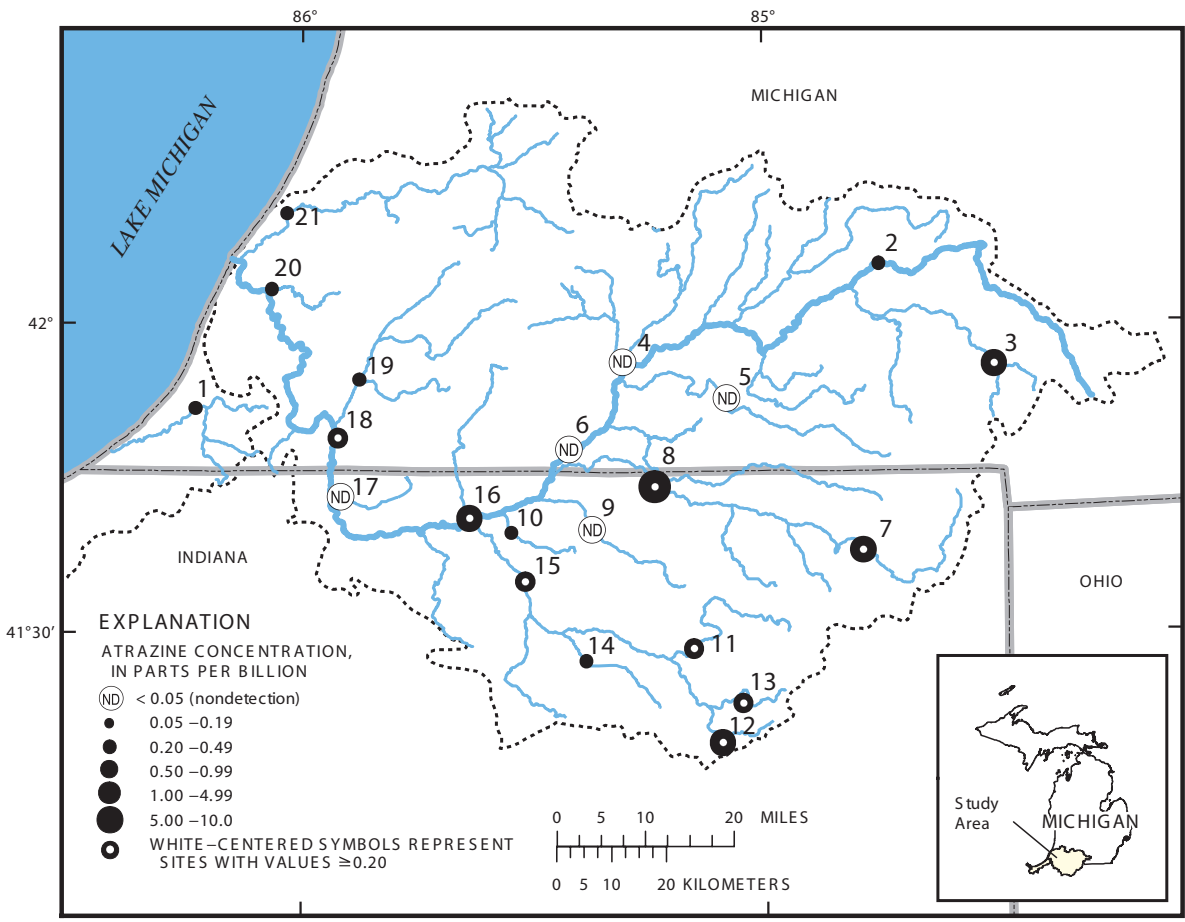

Base from U.S. Environmental Protection Agency, Office of Science and Technology, Reach File 1 for Conterminous United States in BASINS, 1:250,000, 199 U.S. Environmental Protection Agency, Office of Water/OST, Hydrologic Unit Boundaries of the Conterminous United States in BASINS, 1:250,000, 1998

Figure 4. Atrazine concentrations in stream water in the St. Joseph and Galien River Basins, Michigan and Indiana, July 2001. White centered symbols represent atrazine concentrations that exceed the amount determined to feminize frog populations. 


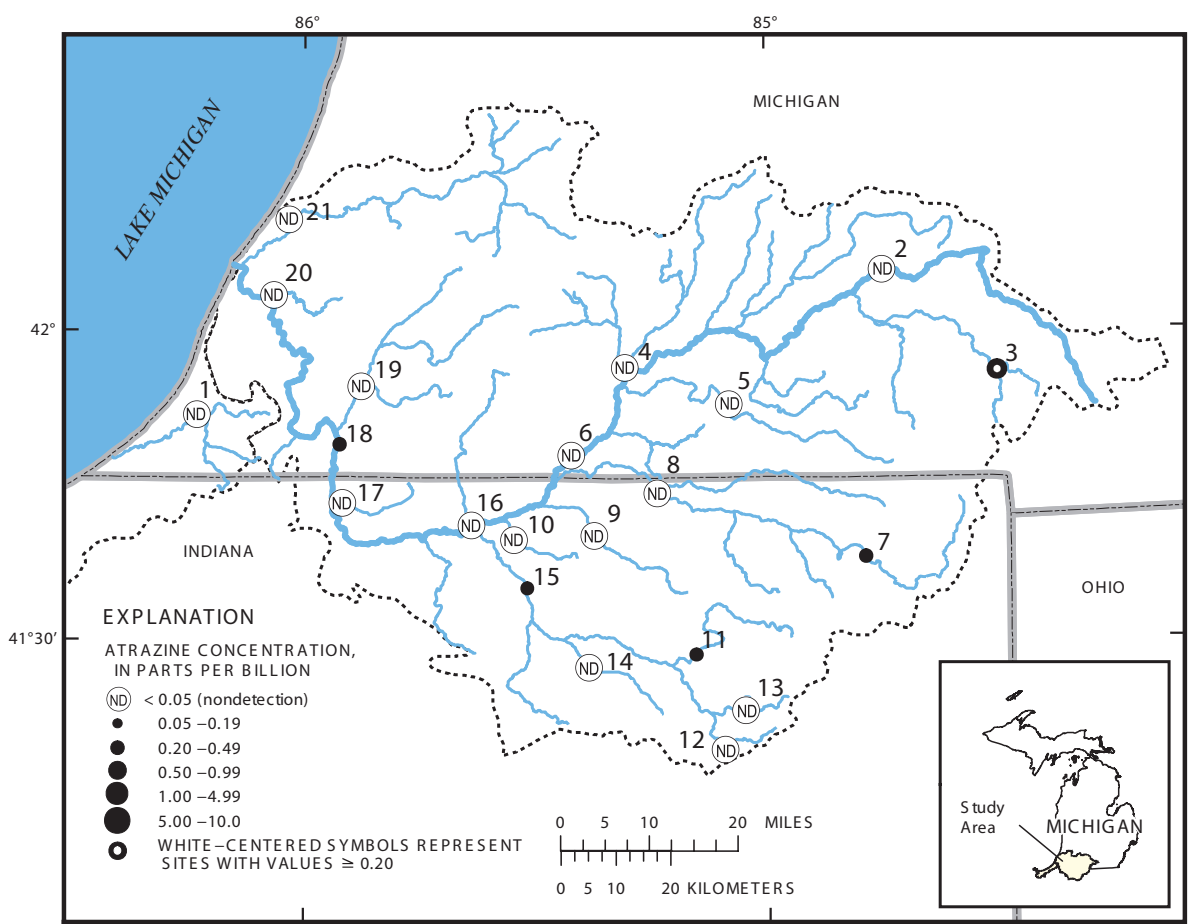

Base from U.S. Environmental Protection Agency, Office of Science and Technology, Reach File 1 for Conterminous United States in BASINS, 1:250,000, 1994 U.S. Environmental Protection Agency, Office of Water/OST, Hydrologic Unit Boundaries of the Conterminous United States in BASINS, 1:250,000, 1998 Michigan GeoRef Projection

Figure 5. Atrazine concentrations in stream water in the St. Joseph and Galien River Basins, Michigan and Indiana, April 2002. White centered symbols represent atrazine concentrations that exceed the amount determined to feminize frog populations.

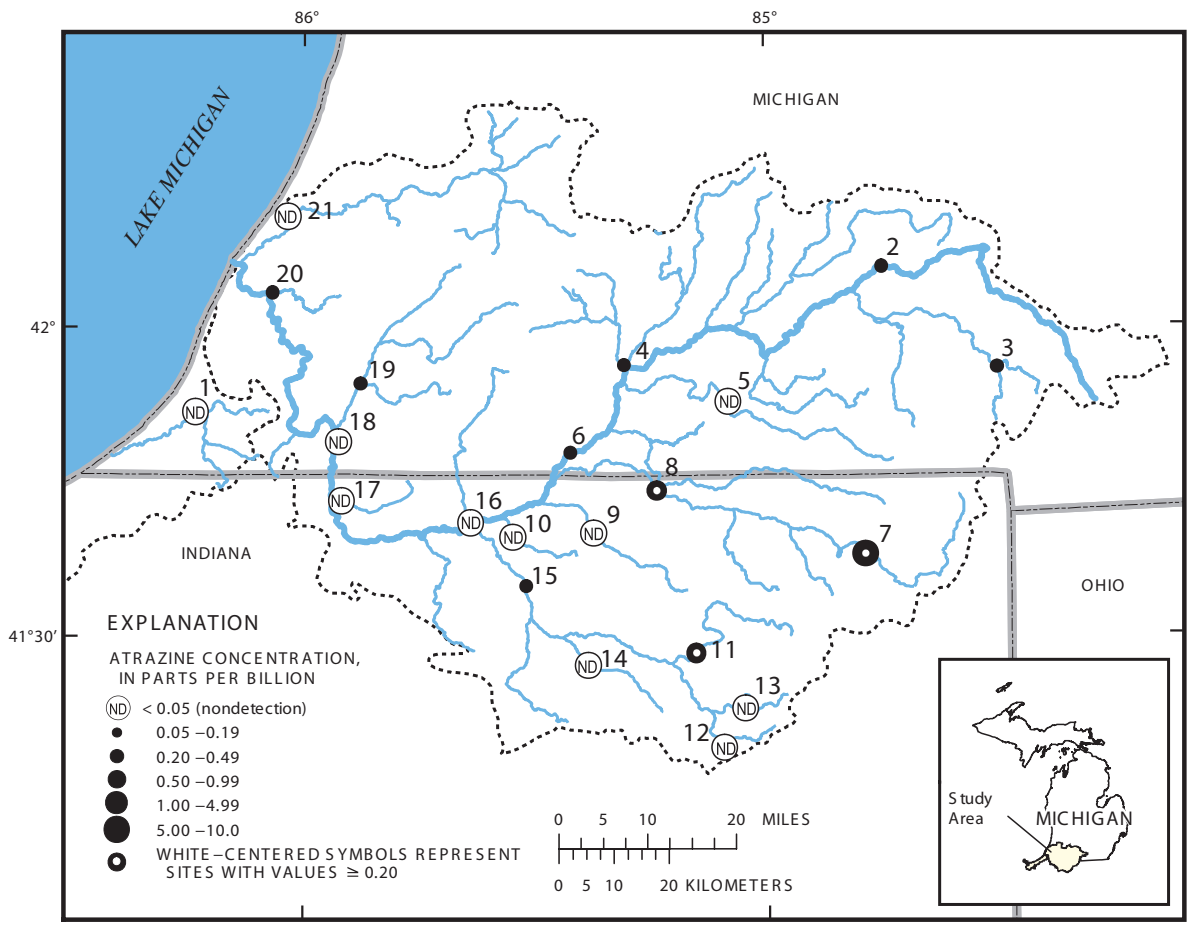

Base from U.S. Environmental Protection Agency, Office of Science and Technology, Reach File 1 for Conterminous United States in BASINS, 1:250,000, 1994 U.S. Environmental Protection Agency, Office of Water/OST, Hydrologic Unit Boundaries of the Conterminous United States in BASINS, 1:250,000, 1998
Michigan GeoRef Projection Michigan GeoRef Projectio

Figure 6. Atrazine concentrations in stream water in the St. Joseph and Galien River Basins, Michigan and Indiana, August 2002. White centered symbols represent atrazine concentrations that exceed the amount determined to feminize frog populations. 
tions greater than $0.2 \mathrm{ppb}$. Concentrations were lower in the Michigan part of the basin than in the Indiana part. Most of the higher concentrations were in the southeast part of the basin. The trend of declining concentration continues for April 2002 samples (fig. 5), which were collected prior to planting. Atrazine concentrations were below detection at 16 sites. The highest concentration was $0.2 \mathrm{ppb}$ at the South Branch of Hog Creek near Allen, Mich. (site 3), and this was the only site with a concentration at the $0.2 \mathrm{ppb}$ level. Detections were scattered across the basin and did not have a spatial pattern.

In August 2002, atrazine concentrations were investigated during low flow. The concentrations followed the general trend shown in the 2001 growing season in that they were between the July 2001 and April 2002 values. Concentrations were below detection level at 11 sites and were greater than $0.2 \mathrm{ppb}$ at only 3 sites. Higher concentrations were found in the southeast part of the basin, although several detections were scattered across the Michigan part of the basin (fig. 6).

Instantaneous loads, computed from the atrazine concentrations and instantaneous discharge at the sites, are shown in figures 7 through 10. The loads followed the concentration pattern, with the largest loads being in May 2001 and the smallest in April and August 2002. Loads were larger in the May 2001 samples because the concentrations were the highest and the instantaneous discharge values were the highest of the four sets of samples. The largest load was $10 \mathrm{~kg} / \mathrm{d}$ for the St. Joseph River at Niles, Mich. (site 18). The largest loads tended to be at sites along the St. Joseph River because the flow rate of the river is so much greater than most of the tributaries measured, and the concentrations at the St. Joseph River sites vary little (fig. 7-10). The minimum load was less than $0.001 \mathrm{~kg} / \mathrm{d}$ for several sites during the August 2002 sampling.

\section{3}

Stream-water atrazine concentrations measured in August and September 2003 are shown in figures 11 and 12, respectively. In August, the mean of stream-water concentrations was $0.15 \mathrm{ppb}$. The minimum atrazine concentration was nondetection at two sites, and the maximum atrazine concentration was $0.35 \mathrm{ppb}$ at St. Joseph River at Niles, Mich. (auxiliary site) (site 48). In September, the mean of streamwater concentrations of atrazine was $0.10 \mathrm{ppb}$. The minimum concentration was $0.08 \mathrm{ppb}$ at the East Branch Galien River at Gardener Road near Glendora, Mich. (site 46). The maximum concentration of atrazine was $0.12 \mathrm{ppb}$ at the Galien River near Sawyer, Mich. (site 1).

\section{Comparison of Atrazine Concentrations in Stream Water and in Streambed Sediment Pore Water}

The stream-water and pore-water concentrations of atrazine measured for the September 2002 sampling are depicted in figures 13 and 14. Arithmetic averages of all stream-water and pore-water atrazine concentrations were 0.21 and $0.20 \mathrm{ppb}$, respectively. The minimum atrazine concentration was nondetection for pore-water and stream-water samples, and the maximum concentration for stream water and pore water was $0.67 \mathrm{ppb}$. Despite similarities in average concentrations, the pore-water and stream-water concentration distributions of atrazine were different. Sites with high pore-water concentrations of atrazine did not necessarily correspond to sites with high stream-water concentrations. The differences between pore-water and stream-water concentrations of atrazine are depicted in figure 15. Stream-water concentrations of atrazine tend to be higher than pore-water concentrations at the same site (fig. 16) However, the concentrations that were below detection were not included in figure 16 . When these concentrations are taken into account the mean stream water atrazine concentration was $0.18 \pm 0.18 \mathrm{ppb}$, while the mean pore water atrazine concentration is $0.17 \pm 0.15 \mathrm{ppb}$, indicating that there is no actual difference between atrazine concentrations in pore water and surface water.

\section{Atrazine Detection Method Comparison}

The concentrations of atrazine and related triazine compounds are summarized in table 2. The field result (ELISA) for the Pigeon River near Scott, Ind., (site 8) in July 2001 was 2 ppb, and the laboratory result was 0.654 $\mathrm{ppb}$. The field result for the sample collected at Solomon Creek near Syracuse, Ind., (site 14) was $0.05 \mathrm{ppb}$, and the corresponding laboratory result was $0.122 \mathrm{ppb}$. The 2-ppb concentration for the sample from the Pigeon River was quite high compared to the other samples collected in July, and there may have been an analytical error. The Solomon Creek sample results are more consistent. For the East Branch Galien River at Gardener Road near Glendora, Mich., (site 46) the field value was $0.12 \mathrm{ppb}$, whereas the lab result was $0.085 \mathrm{ppb}$; and for the Galien River near Sawyer, Mich., (site 1) the field value was $0.08 \mathrm{ppb}$ and the lab value was $0.043 \mathrm{ppb}$.

The average field concentration of atrazine at the four sites tested with both methods was $0.56 \mathrm{ppb}$, whereas the average laboratory concentration for all of the field-screen detected derivatives and other triazine pesticides for the same four sites was $0.23 \mathrm{ppb}$. The fact that the field concentration is higher is expected because the field method detects many atrazine derivatives and breakdown products, whereas the laboratory analysis is specific for atrazine and three related triazines. However, the presence of atrazine in field tests was verified by laboratory analysis in every comparison. Additional water quality data and laboratory results of pesticide screen are presented in tables 3 and 4 respectively. 


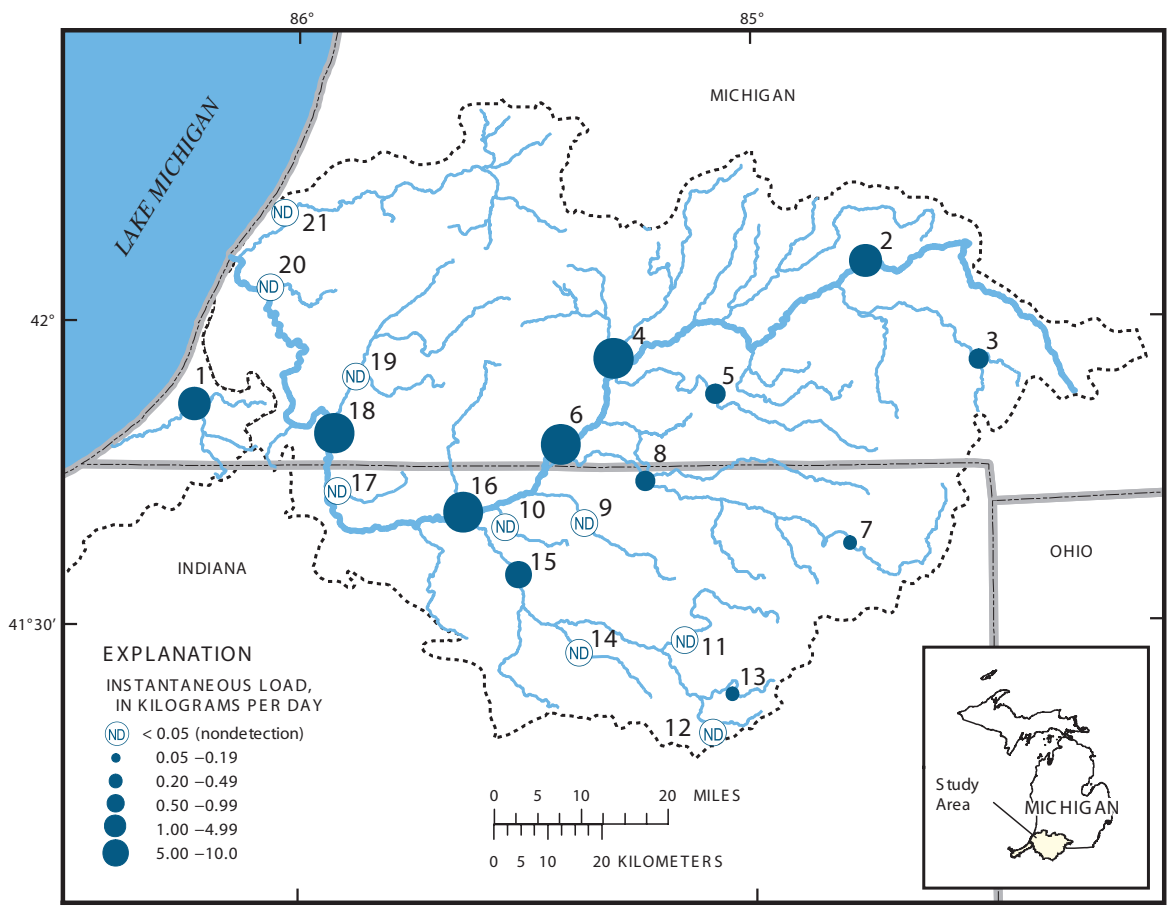

Base from U.S. Environmental Protection Agency, Office of Science and Technology, Reach File 1 for Conterminous United States in BASINS, 1:250,000, 1994 U.S. Environmental Protection Agency, Office of Water/OST, Hydrologic Unit Boundaries of the Conterminous United States in BASINS, 1:250,000, 1998
Michigan GeoRef Projection

Figure 7. Instantaneous loads of atrazine in stream water in the St. Joseph and Galien River Basins, Michigan and Indiana, May 2001.

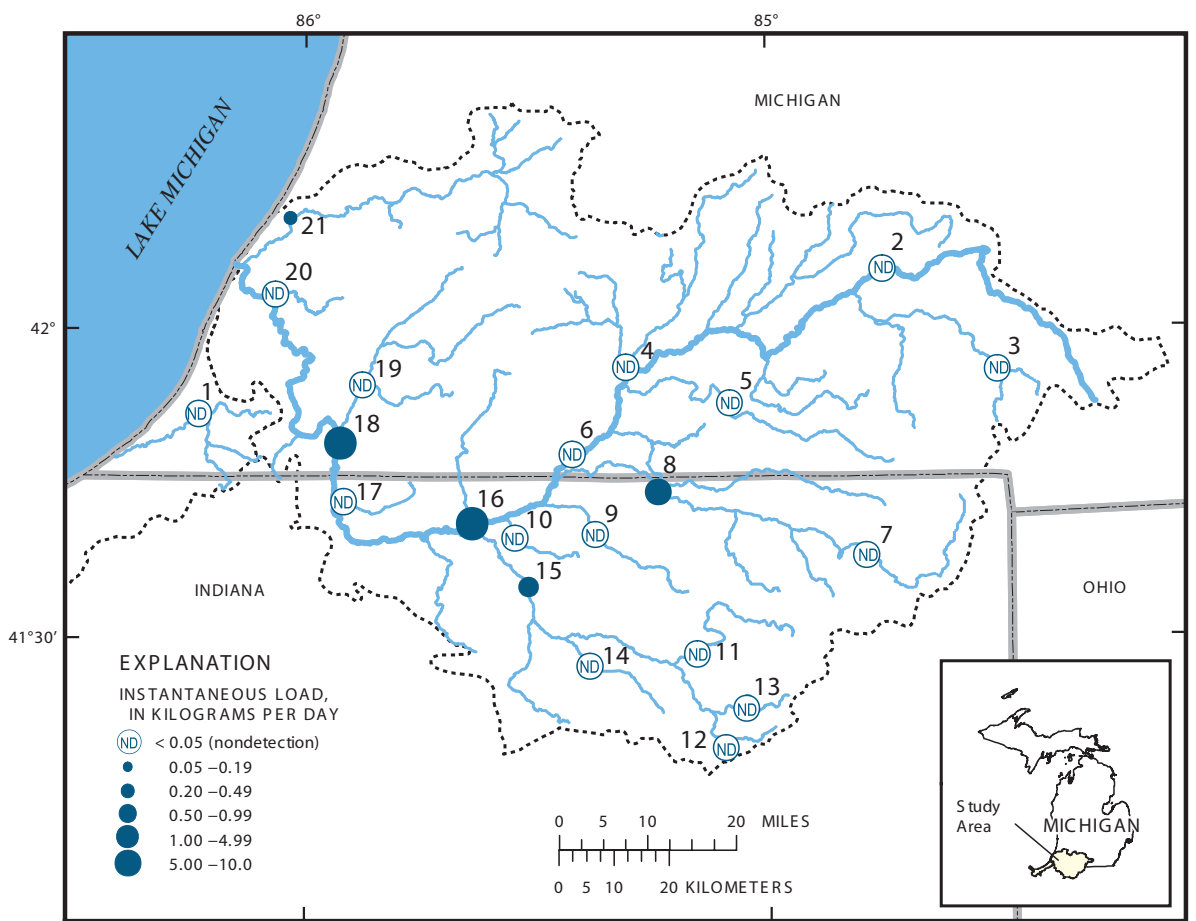

Base from U.S. Environmental Protection Agency, Office of Science and Technology, Reach File 1 for Conterminous United States in BASINS, 1:250,000, 1994 U.S. Environmental Protection Agency, Office of Water/OST, Hydrologic Unit Boundaries of the Conterminous United States in BASINS, 1:250,000, 1998 Michigan GeoRef Projection

Figure 8. Instantaneous loads of atrazine in stream water in the St. Joseph and Galien River Basins, Michigan and Indiana, July 2001. 


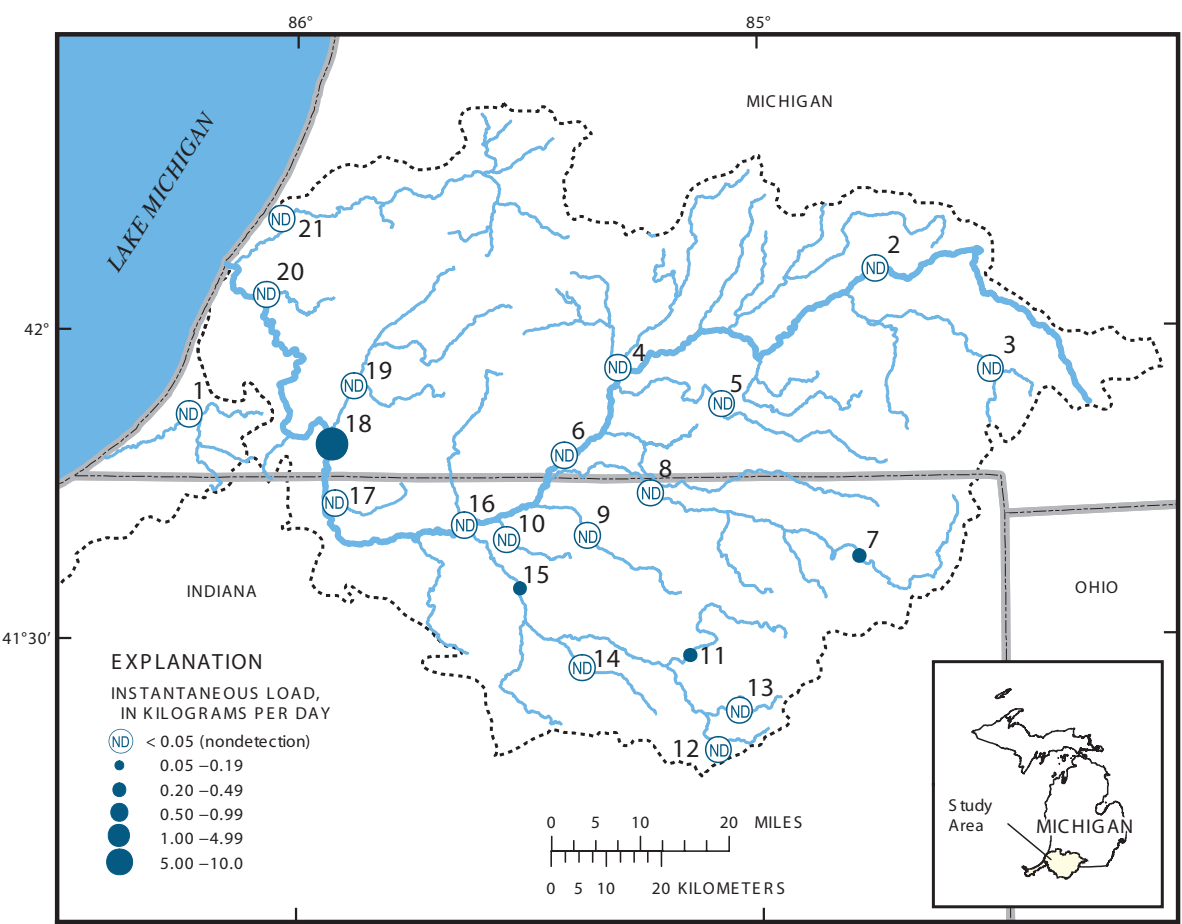

Base from U.S. Environmental Protection Agency, Office of Science and Technology, Reach File 1 for Conterminous United States in BASINS, 1:250,000, 1994 U.S. Environmental Protection Agency, Office of Water/OST, Hydrologic Unit Boundaries of the Conterminous United States in BASINS, 1:250,000, 1998
Michigan GeoRef Projection

Figure 9. Instantaneous loads of atrazine in stream water in the St. Joseph and Galien River Basins, Michigan and Indiana, April 2002.

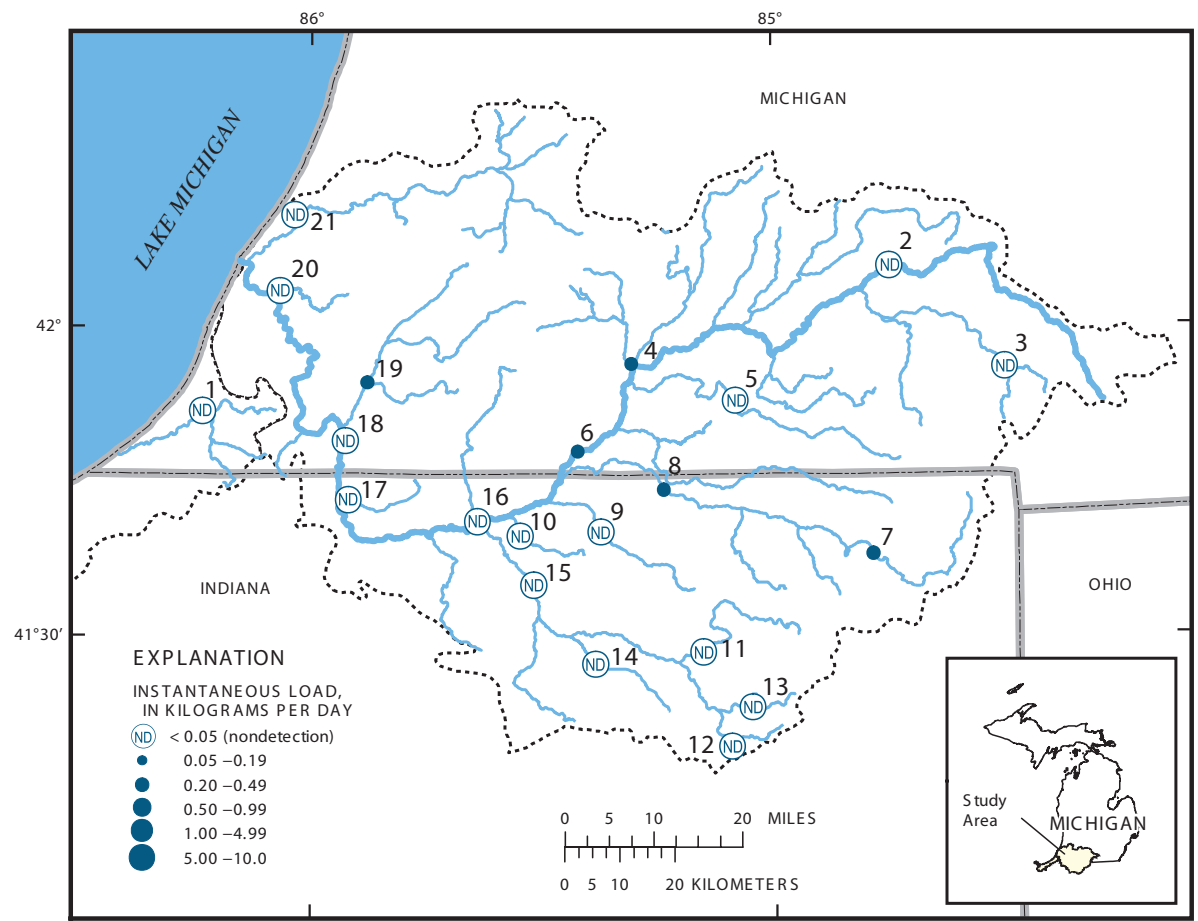

Base from U.S. Environmental Protection Agency, Office of Science and Technology, Reach File 1 for Conterminous United States in BASINS, 1:250,000, 1994 U.S. Environmental Protection Agency, Office of Water/OST, Hydrologic Unit Boundaries of the Conterminous United States in BASINS, 1:250,000, 1998
Michigan GeoRef Projection

Figure 10. Instantaneous loads of atrazine in stream water in the St. Joseph and Galien River Basins, Michigan and Indiana, August 2002. 


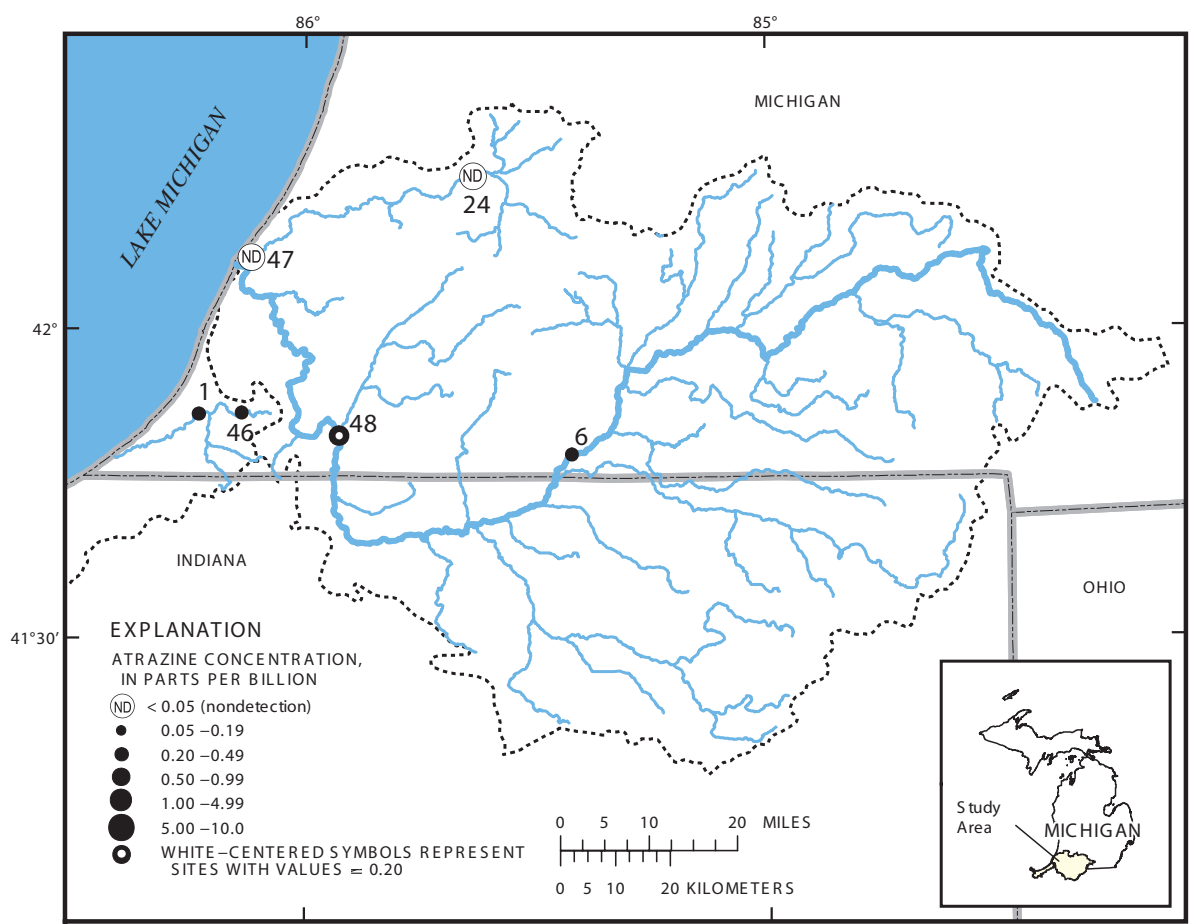

Base from U.S. Environmental Protection Agency, Office of Science and Technology, Reach File 1 for Conterminous United States in BASINS, 1:250,000, 1994 U.S. Environmental Protection Agency, Office of Water/OST, Hydrologic Unit Boundaries of the Conterminous United States in BASINS, 1:250,000, 1998 Michigan GeoRef Projection

Figure 11. Atrazine concentrations in stream water in the St. Joseph and Galien River Basins, Michigan and Indiana, August 2003. White centered symbols represent atrazine concentrations that exceed the amount determined to feminize frog populations.

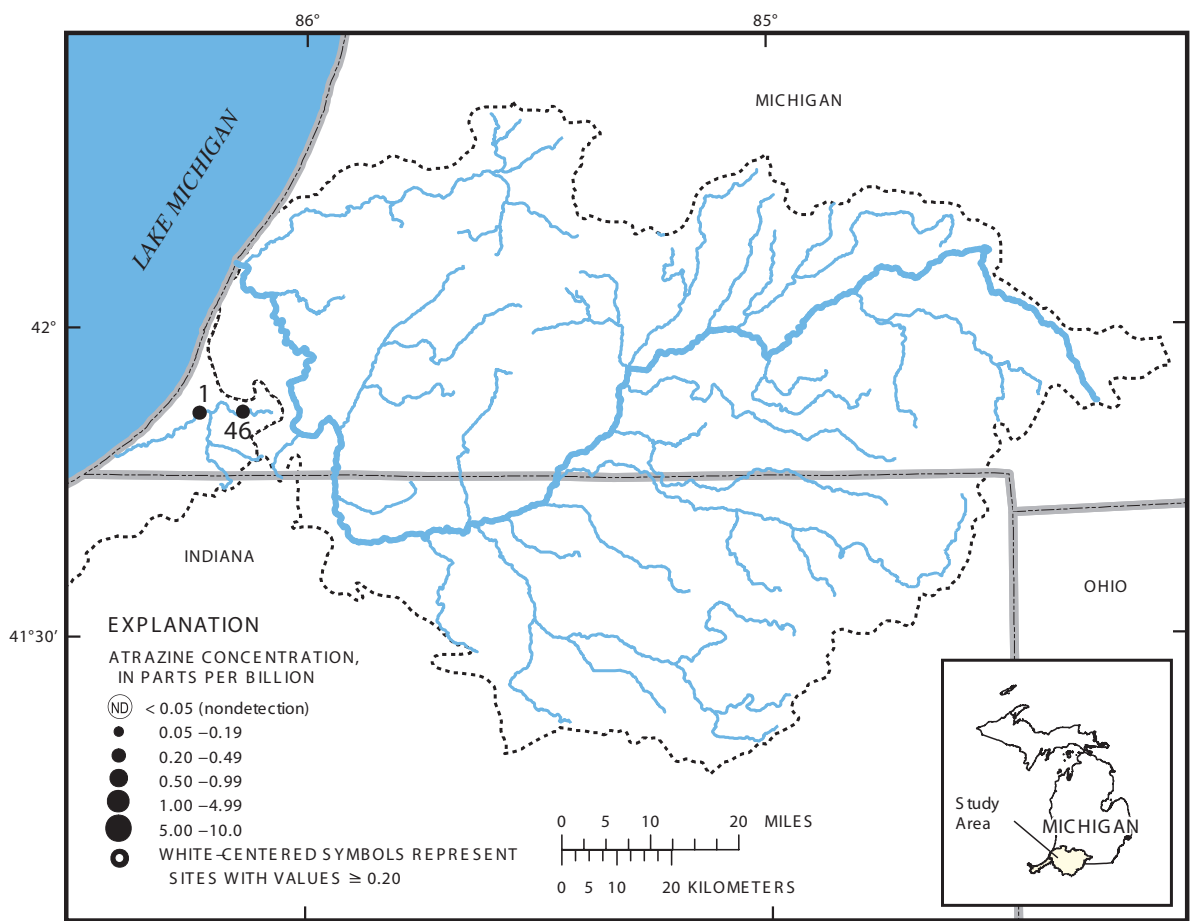

Base from U.S. Environmental Protection Agency, Office of Science and Technology, Reach File 1 for Conterminous United States in BASINS, 1:250,000, 1994 U.S. Environmental Protection Agency, Office of Water/OST, Hydrologic Unit Boundaries of the Conterminous United States in BASINS, 1:250,000, 1998
Michigan GeoRef Projection

Figure 12. Atrazine concentrations in stream water in the St. Joseph and Galien River Basins, Michigan and Indiana, September 2003. White centered symbols represent atrazine concentrations that exceed the amount determined to feminize frog populations. 


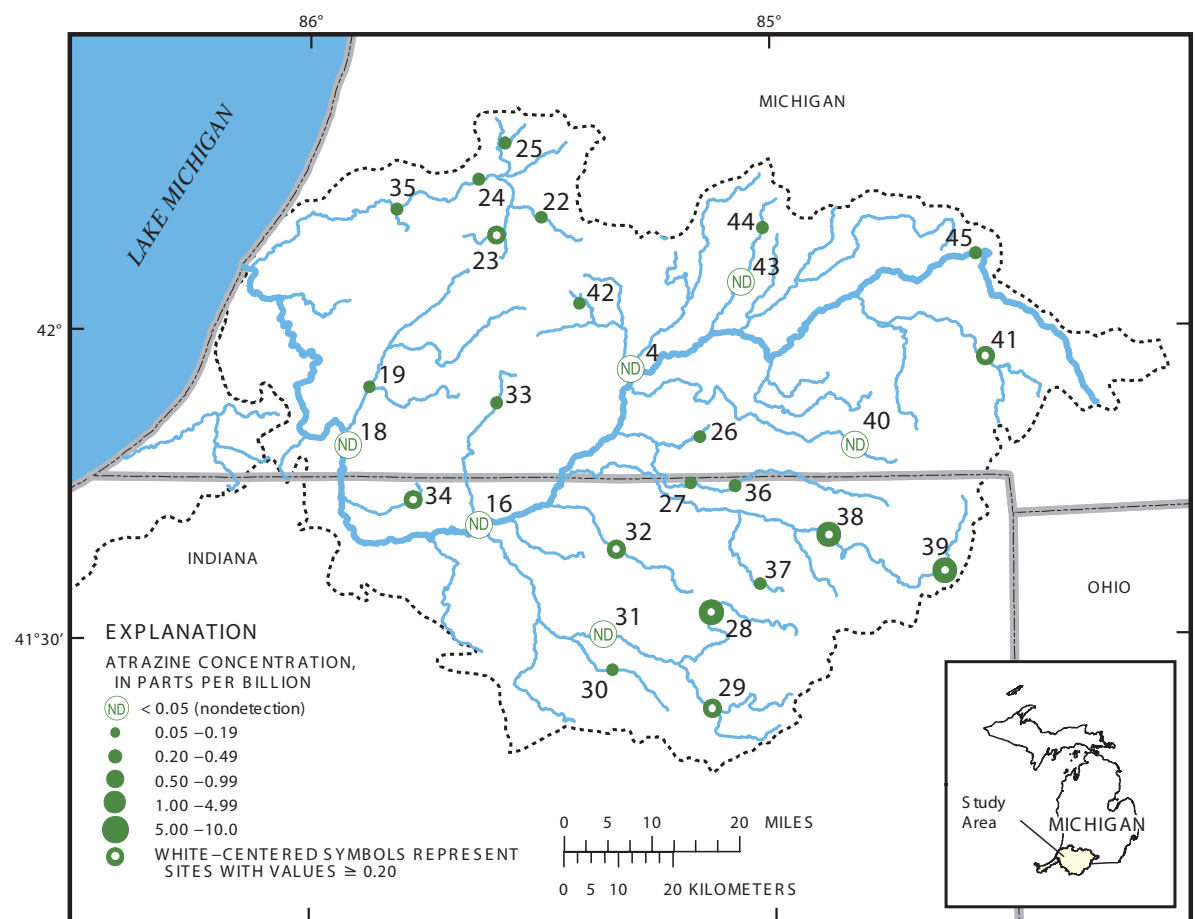

Base from U.S. Environmental Protection Agency, Office of Science and Technology, Reach File 1 for Conterminous United States in BASINS, 1:250,000, 1994 U.S. Environmental Protection Agency, Office of Water/OST, Hydrologic Unit Boundaries of the Conterminous United States in BASINS, 1:250,000, 1998
Michigan GeoRef Projection

Figure 13. Mean atrazine concentrations in stream water in the St. Joseph and Galien River Basins, Michigan and Indiana, September 2002. White centered symbols represent atrazine concentrations that exceed the amount determined to feminize frog populations.

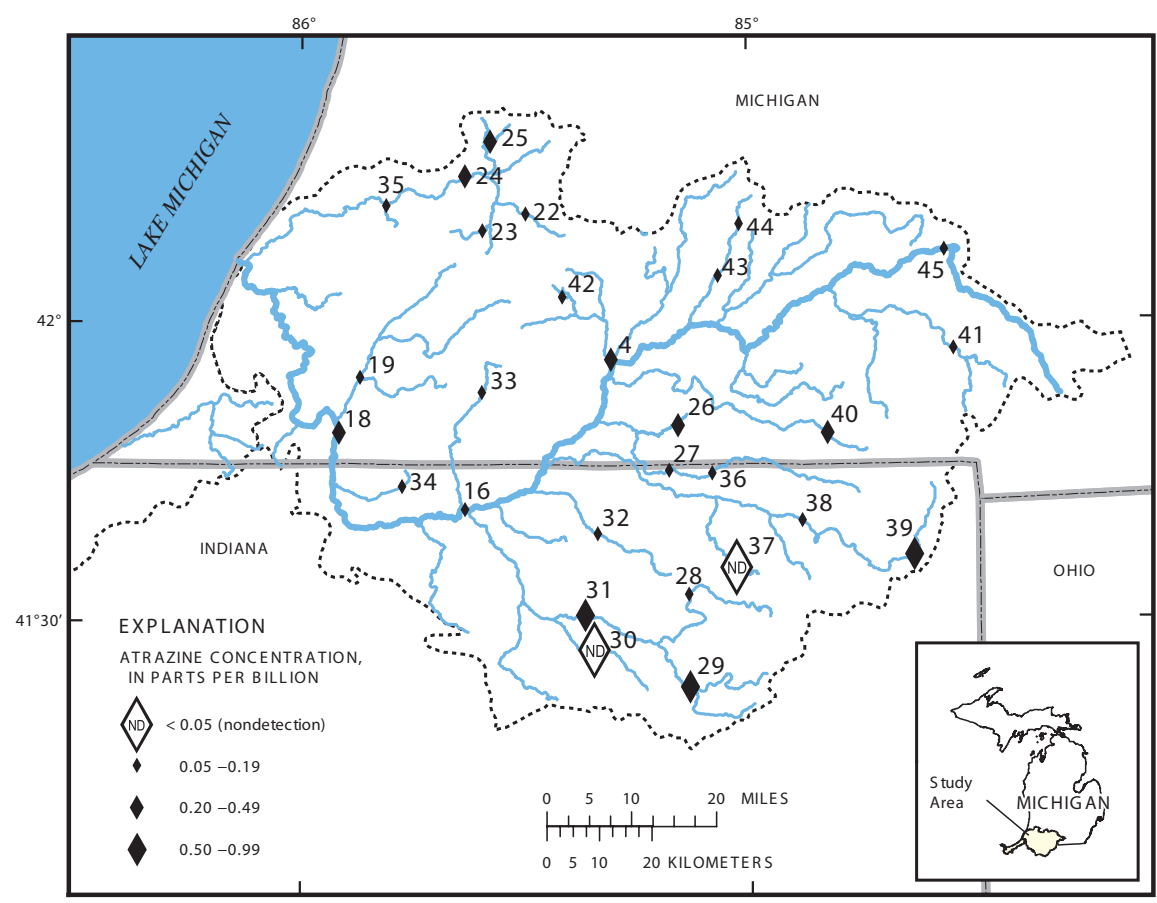

Base from U.S. Environmental Protection Agency, Office of Science and Technology, Reach File 1 for Conterminous United States in BASINS, 1:250,000, 1994 U.S. Environmental Protection Agency, Office of Water/OST, Hydrologic Unit Boundaries of the Conterminous United States in BASINS, 1:250,000, 1998

Figure 14. Mean atrazine concentrations in streambed sediment pore water in the St. Joseph and Galien River Basins, Michigan and Indiana, September 2002. 


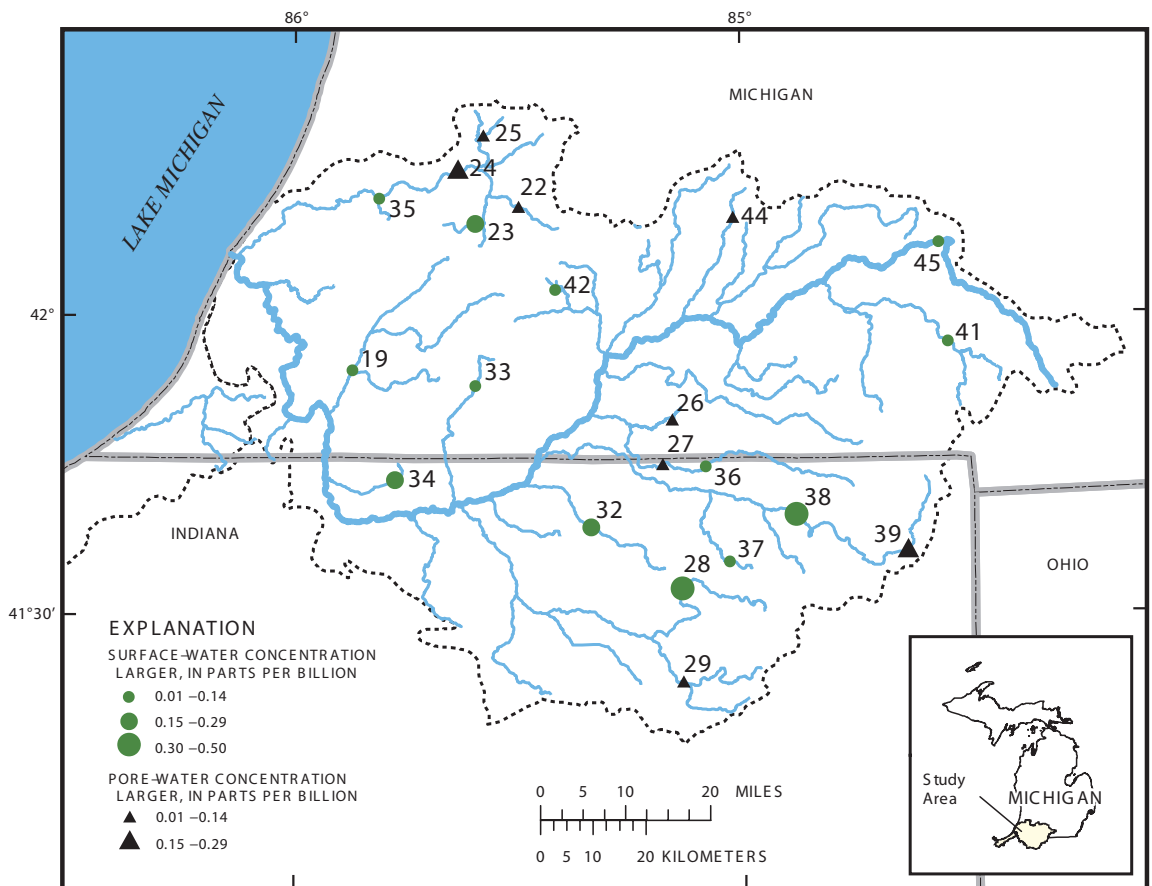

Base from U.S. Environmental Protection Agency, Office of Science and Technology, Reach File 1 for Conterminous United States in BASINS, 1:250,000, 1994 U.S. Environmental Protection Agency, Office of Water/OST, Hydrologic Unit Boundaries of the Conterminous United States in BASINS, 1:250,000, 1998 Michigan GeoRef Projection

Figure 15. Difference between atrazine concentrations in stream water and streambed sediment pore water in the St. Joseph and Galien River Basins, Michigan and Indiana, September 2002.

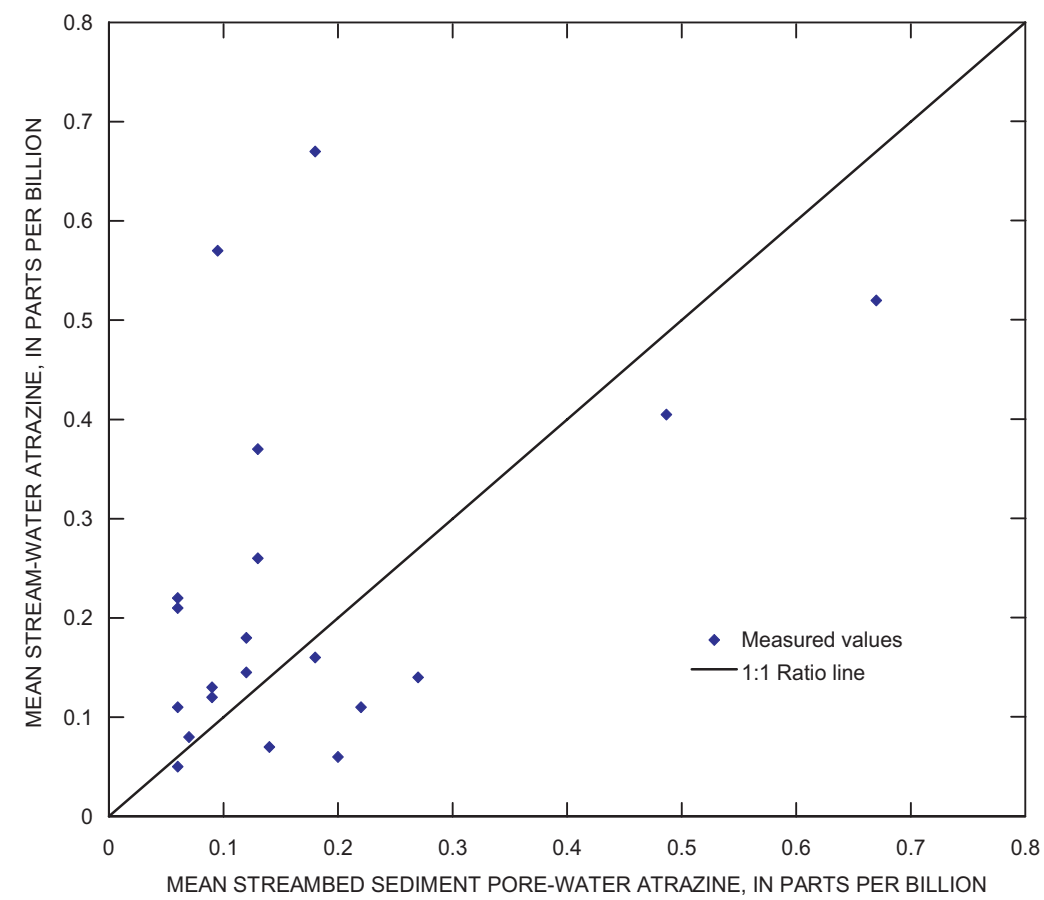

Figure 16. Relation of pore-water to stream-water atrazine concentrations in the St. Joseph and Galien River Basins, Michigan and Indiana, September 2002. 
Table 2. Comparison of field ELISA triazine screen and laboratory C-18 chromatography atrazine results. [abbreviations; USGS, U.S. Geological Survey]

\begin{tabular}{|c|c|c|c|c|c|}
\hline USGS station name & USGS station number & Map number & Date sampled & $\begin{array}{l}\text { Triazine screen } \\
\text { (Field) }\end{array}$ & $\begin{array}{c}\text { Triazine screen } \\
(\mathrm{Lab})^{*}\end{array}$ \\
\hline Pigeon River near Scott, Ind. & 04099750 & 8 & $7 / 10 / 2001$ & 2.00 & 0.655 \\
\hline Solomon Creek near Syracuse, Ind. & 04100377 & 14 & $7 / 11 / 2001$ & .05 & 0.126 \\
\hline $\begin{array}{l}\text { East Branch Galien River at Gardener } \\
\text { Road near Glendora, Mich. }\end{array}$ & 04095995 & 46 & $9 / 2 / 2003$ & .12 & 0.087 \\
\hline Galien River near Sawyer, Mich. & 04096015 & 1 & $9 / 2 / 2003$ & .08 & 0.051 \\
\hline
\end{tabular}

*This accounts for all compounds in schedule 2001 that fall into the triazine screen. These include:

For the Triazine Field Screen: Atrazine, propazine, ametryn, prometryn, prometon, desethyl atrazine, terbutryn, terbutylazine, simazine,

desisopropyl atrazine, cyanazine and 2-hydroxy atrazine.

Schedule 2001 includes: atrazine, cyanazine, prometon, simazine.

Table 3. Additional water-quality data in the St. Joseph and Galien River Basins, Michigan and Indiana [abbreviations; USGS, U.S. Geological Survey; ND, nondetection; 1, not measured]

\begin{tabular}{|c|c|c|c|c|c|c|c|c|c|}
\hline \multirow{3}{*}{ USGS Station Number } & \multirow{3}{*}{ USGS Station Name } & \multirow{3}{*}{ Date } & \multirow{3}{*}{$\begin{array}{c}\text { Discharge } \\
\left(\mathrm{ft}^{3} / \mathrm{s}\right)\end{array}$} & \multirow{3}{*}{$\begin{array}{c}\text { Dissolved } \\
\text { Oxygen } \\
\text { (mg/L) }\end{array}$} & \multirow{3}{*}{$\begin{array}{c}\mathrm{pH} \\
\mathrm{pH} \text { units }\end{array}$} & \multirow{3}{*}{$\begin{array}{c}\text { Specific } \\
\text { Conductance } \\
(\mu \mathrm{S} / \mathrm{cm})\end{array}$} & \multirow{3}{*}{$\begin{array}{c}\text { Temperature } \\
\text { (Deg. C) }\end{array}$} & \multicolumn{2}{|c|}{ Triazine Screen } \\
\hline & & & & & & & & $\begin{array}{c}\text { Stream } \\
\text { water }\end{array}$ & $\begin{array}{l}\text { Pore } \\
\text { water }\end{array}$ \\
\hline & & & & & & & & $(\mu \mathrm{g} / \mathrm{L})$ & $(\mu \mathrm{g} / \mathrm{L})$ \\
\hline 04102240 & Brandywine Creek at $37^{\text {th }}$ Street near Gobles, MI & $8 / 26 / 2002$ & - & - & - & - & - & 0.14 & 0.27 \\
\hline 04099962 & Christiana Creek at Brownsville Street near Vandalia, MI & $8 / 28 / 2002$ & - & - & - & - & - & .12 & .09 \\
\hline 04101800 & Dowagiac River at Sumnerville, MI & $8 / 28 / 2002$ & - & - & - & - & - & .11 & .06 \\
\hline 04101800 & Dowagiac River at Sumnerville, Mich. & $5 / 21 / 2001$ & 207.00 & 8.43 & 7.84 & 520.0 & 16.94 & .09 & - \\
\hline 04101800 & Dowagiac River at Sumnerville, Mich. & $7 / 11 / 2001$ & 150.00 & 6.35 & 8.49 & - & 22.86 & .08 & - \\
\hline 04101800 & Dowagiac River at Sumnerville, Mich. & $4 / 15 / 2002$ & 343.00 & 10.65 & 7.81 & 191.0 & 16.55 & ND & - \\
\hline 04101800 & Dowagiac River at Sumnerville, Mich. & $8 / 6 / 2002$ & 209.00 & 7.55 & 7.67 & 518.0 & 20.81 & .13 & - \\
\hline 04102139 & Eagle Lake Drain at $39^{\text {th }}$ Street near Lawton, MI & $8 / 26 / 2002$ & - & - & - & - & - & .22 & .06 \\
\hline 04095995 & East Branch Galien River at Gardener Road near Glendora, Mich. & $8 / 19 / 2003$ & - & 6.77 & 8.38 & 602.8 & 18.29 & .10 & - \\
\hline 04095995 & East Branch Galien River at Gardener Road near Glendora, Mich. & $9 / 2 / 2003$ & - & 7.49 & 8.27 & 565.8 & 17.34 & .12 & - \\
\hline 04102172 & East Branch Paw Paw River at $28^{\text {th }}$ Street near Mattawan, MI & $8 / 26 / 2002$ & - & - & - & - & - & .16 & .18 \\
\hline 04100500 & Elkhart River at Goshen, Ind. & $5 / 25 / 2001$ & 414.00 & 10.12 & 7.91 & 616.0 & 15.34 & .52 & - \\
\hline 04100500 & Elkhart River at Goshen, Ind. & 7/9/2001 & 333.00 & 6.08 & 6.71 & 13.0 & 27.40 & .38 & - \\
\hline 04100500 & Elkhart River at Goshen, Ind. & $4 / 17 / 2002$ & 1420.00 & 9.73 & 7.90 & 572.0 & 20.00 & .05 & - \\
\hline 04100500 & Elkhart River at Goshen, Ind. & $8 / 7 / 2002$ & 177.00 & 7.92 & 7.20 & 652.0 & 23.20 & .10 & - \\
\hline 04100372 & Elkhart River at Highway 13 near Millersburg, IN & $8 / 27 / 2002$ & - & - & - & - & - & .03 & .51 \\
\hline 04098325 & Fawn River at 125 East Road near Howe, IN & $8 / 29 / 2002$ & - & - & - & - & - & .08 & .07 \\
\hline 04098465 & Fawn River at 400 West Road near Scott, IN & $8 / 29 / 2002$ & - & - & - & - & - & .07 & .14 \\
\hline 04099662 & Fly Creek at County Road 400 East near LaGrange, IN & $8 / 29 / 2002$ & - & - & - & - & - & .05 & ND \\
\hline 04100252 & Forker Creek near Burr Oak, Ind. & $5 / 25 / 2001$ & 10.00 & 8.35 & 7.66 & 428.0 & 18.33 & .20 & - \\
\hline 04100252 & Forker Creek near Burr Oak, Ind. & $7 / 10 / 2001$ & 2.60 & 6.11 & 5.29 & 456.0 & 25.37 & .76 & - \\
\hline 04100252 & Forker Creek near Burr Oak, Ind. & $4 / 17 / 2002$ & 28.00 & 10.38 & 8.07 & 440.0 & 19.57 & ND & - \\
\hline 040973493 & Four County Drain at Bowers Road near Flowerfield, MI & $8 / 30 / 2002$ & - & - & - & - & - & .15 & .12 \\
\hline 04096015 & Galien River near Sawyer, Mich. & $5 / 22 / 2001$ & 83.40 & 8.68 & 7.68 & 537.0 & 14.71 & 5.95 & - \\
\hline 04096015 & Galien River near Sawyer, Mich. & $7 / 11 / 2001$ & 29.10 & 6.48 & 8.12 & - & 23.68 & .19 & - \\
\hline 04096015 & Galien River near Sawyer, Mich. & $4 / 16 / 2002$ & 80.30 & 7.86 & 7.41 & 577.0 & 16.19 & $\mathrm{ND}$ & - \\
\hline 04096015 & Galien River near Sawyer, Mich. & $8 / 6 / 2002$ & 19.60 & 8.82 & 7.54 & 620.0 & 19.69 & ND & - \\
\hline 04096015 & Galien River near Sawyer, Mich. & $8 / 19 / 2003$ & - & 7.69 & 8.32 & 623.1 & 18.21 & .06 & - \\
\hline 04096015 & Galien River near Sawyer, Mich. & $9 / 2 / 2003$ & - & 8.28 & 7.50 & 560.4 & 16.26 & .08 & - \\
\hline 04102405 & Hog Creek at $62^{\text {nd }}$ Street near Hartford, MI & $8 / 28 / 2002$ & - & - & - & - & - & .13 & .09 \\
\hline 414331086063801 & Juday Creek at Bittersweet Road near Granger, IN & $8 / 28 / 2002$ & - & - & - & - & - & .21 & .06 \\
\hline 04101370 & Juday Creek near South Bend, Ind. & $5 / 21 / 2001$ & 10.00 & 8.99 & 8.02 & 712.0 & 17.92 & .07 & - \\
\hline 04101370 & Juday Creek near South Bend, Ind. & $7 / 11 / 2001$ & 7.10 & - & - & 0.0 & 24.33 & ND & - \\
\hline 04101370 & Juday Creek near South Bend, Ind. & $4 / 15 / 2002$ & 25.00 & 11.84 & 8.08 & 726.0 & 18.55 & ND & - \\
\hline 04101370 & Juday Creek near South Bend, Ind. & $8 / 6 / 2002$ & 7.70 & 8.25 & 8.01 & 708.0 & 22.35 & ND & - \\
\hline 04099804 & Little Elkhart River at 50 North Road near Middlebury, IN & $8 / 27 / 2002$ & - & - & - & - & - & .37 & .13 \\
\hline 04099808 & Little Elkhart River at Middlebury, Ind. & $5 / 24 / 2001$ & 70.00 & 8.54 & 7.82 & 662.0 & 11.95 & .09 & - \\
\hline 04099808 & Little Elkhart River at Middlebury, Ind. & 7/9/2001 & 37.00 & 6.92 & 8.59 & 14.0 & 26.83 & ND & - \\
\hline 04099808 & Little Elkhart River at Middlebury, Ind. & $4 / 17 / 2002$ & 116.00 & 8.41 & 7.74 & 723.0 & 15.23 & ND & - \\
\hline 04099808 & Little Elkhart River at Middlebury, Ind. & $8 / 7 / 2002$ & 43.00 & 8.20 & 7.80 & 696.0 & 19.07 & ND & - \\
\hline 04097060 & Little Portage Creek at $38^{\text {th }}$ Street near Fulton, MI & $8 / 30 / 2002$ & - & - & - & - & - & ND & .10 \\
\hline
\end{tabular}


Table 3. Additional water-quality data in the St. Joseph and Galien River Basins, Michigan and Indiana--Continued

\begin{tabular}{|c|c|c|c|c|c|c|c|c|c|}
\hline \multirow[b]{2}{*}{ Station ID } & \multirow[b]{2}{*}{ Station Name } & \multirow[b]{2}{*}{ Date } & \multirow[b]{2}{*}{$\begin{array}{c}\text { Discharge } \\
\left(\mathrm{ft}^{3} / \mathrm{s}\right)\end{array}$} & \multirow[b]{2}{*}{$\begin{array}{c}\text { Dissolved } \\
\text { Oxygen } \\
(\mathrm{mg} / \mathrm{L})\end{array}$} & \multirow[b]{2}{*}{$\begin{array}{c}\mathrm{pH} \\
\mathrm{pH} \text { units }\end{array}$} & \multirow[b]{2}{*}{$\begin{array}{c}\text { Specific } \\
\text { Conductance } \\
(\mu \mathrm{S} / \mathrm{cm})\end{array}$} & \multirow[b]{2}{*}{$\begin{array}{c}\text { Temperature } \\
\text { (Deg. C) }\end{array}$} & \multicolumn{2}{|c|}{ Triazine Screen } \\
\hline & & & & & & & & $\begin{array}{c}\text { Stream } \\
\text { water } \\
(\mu \mathrm{g} / \mathrm{L})\end{array}$ & $\begin{array}{c}\text { Pore } \\
\text { water } \\
(\mu \mathrm{g} / \mathrm{L})\end{array}$ \\
\hline 04097038 & Little Portage Creek at S Avenue near Climax, MI & $8 / 30 / 2002$ & - & - & - & - & - & .05 & .06 \\
\hline 04100122 & North Branch Elkhart River at 700 South Road near Eddy, IN & $8 / 27 / 2002$ & - & - & - & - & - & 67 & .18 \\
\hline 04100222 & North Branch Elkhart River at Cosperville, Ind. & $5 / 25 / 2001$ & 72.00 & 7.59 & 7.86 & 541.0 & 16.40 & .18 & - \\
\hline 04100222 & North Branch Elkhart River at Cosperville, Ind. & $7 / 10 / 2001$ & 34.00 & 5.60 & 11.53 & 12.0 & 31.96 & .36 & - \\
\hline 04100222 & North Branch Elkhart River at Cosperville, Ind. & $4 / 17 / 2002$ & 407.00 & 9.54 & 8.03 & 538.0 & 18.56 & .06 & - \\
\hline 04100222 & North Branch Elkhart River at Cosperville, Ind. & $8 / 14 / 2002$ & 30.00 & 3.92 & 6.34 & 493.0 & 22.29 & .39 & - \\
\hline 04102324 & Paw Paw River at $44^{\text {th }}$ Avenue near Paw Paw, MI & $8 / 26 / 2002$ & - & - & - & - & - & .06 & .20 \\
\hline 04102324 & Paw Paw River at 44th Avenue near Paw Paw, Mich. & $8 / 18 / 2003$ & - & 7.84 & 7.80 & 485.4 & 21.84 & ND & - \\
\hline 04102521 & Paw Paw River at North Shore Drive, near Benton Harbor, Mich. & $8 / 19 / 2003$ & - & 7.10 & 7.84 & 517.3 & 20.15 & ND & - \\
\hline 04102500 & Paw Paw River at Riverside, Mich. & $5 / 22 / 2001$ & 337.00 & 7.94 & 7.80 & 500.0 & 16.70 & ND & - \\
\hline 04102500 & Paw Paw River at Riverside, Mich. & $7 / 12 / 2001$ & 231.00 & 7.25 & 6.74 & 519.0 & 20.32 & .19 & - \\
\hline 04102500 & Paw Paw River at Riverside, Mich. & $4 / 15 / 2002$ & 650.00 & 12.13 & 8.13 & 469.0 & 16.65 & ND & - \\
\hline 04102500 & Paw Paw River at Riverside, Mich. & $8 / 6 / 2002$ & 291.00 & 6.84 & 7.49 & 476.0 & 21.60 & ND & - \\
\hline 04099522 & Pigeon Creek at County Road 1175E near Orland, IN & $8 / 29 / 2002$ & - & - & - & - & - & .57 & .01 \\
\hline 04099510 & Pigeon Creek near Angola, Ind. & $5 / 23 / 2001$ & 95.00 & 9.64 & 8.09 & 726.0 & 19.83 & .78 & - \\
\hline 04099510 & Pigeon Creek near Angola, Ind. & $7 / 9 / 2001$ & 37.00 & 9.81 & 5.98 & 13.0 & 30.81 & .55 & - \\
\hline 04099510 & Pigeon Creek near Angola, Ind. & $4 / 17 / 2002$ & 312.00 & 11.82 & 7.99 & 541.0 & 17.33 & .10 & - \\
\hline 04099510 & Pigeon Creek near Angola, Ind. & $8 / 14 / 2002$ & 27.00 & 8.41 & 6.02 & 577.0 & 24.31 & 1.14 & - \\
\hline 04099070 & Pigeon Creek near Hamilton, IN & $8 / 29 / 2002$ & - & - & - & - & - & 0.52 & 0.67 \\
\hline 04099750 & Pigeon River near Scott, Ind. & $5 / 23 / 2001$ & 309.00 & 9.32 & 8.03 & 630.0 & 17.92 & .33 & - \\
\hline 04099750 & Pigeon River near Scott, Ind. & $7 / 9 / 2001$ & 179.00 & 7.18 & 6.18 & 13.0 & 29.93 & 2.09 & - \\
\hline 04099750 & Pigeon River near Scott, Ind. & $4 / 17 / 2002$ & 840.00 & 7.64 & 7.82 & 574.0 & 18.67 & ND & - \\
\hline 04099750 & Pigeon River near Scott, Ind. & $8 / 7 / 2002$ & 140.00 & 8.67 & 7.92 & 588.0 & 22.13 & .21 & - \\
\hline 04099850 & Pine Creek near Elkhart, Ind. & $5 / 24 / 2001$ & 11.00 & 9.27 & 7.91 & 675.0 & 12.71 & .19 & - \\
\hline 04099850 & Pine Creek near Elkhart, Ind. & $7 / 10 / 2001$ & 5.90 & 8.02 & 12.80 & 14.0 & - & .10 & - \\
\hline 04099850 & Pine Creek near Elkhart, Ind. & $4 / 17 / 2002$ & 21.00 & 9.42 & 7.42 & 688.0 & 14.94 & ND & - \\
\hline 04099850 & Pine Creek near Elkhart, Ind. & $8 / 7 / 2002$ & 16.00 & 10.20 & 7.40 & 685.0 & 19.89 & ND & - \\
\hline 04100295 & Rimmell Branch near Albion, Ind. & $5 / 25 / 2001$ & 8.80 & 9.99 & 7.55 & 724.0 & 12.79 & 2.80 & - \\
\hline 04100295 & Rimmell Branch near Albion, Ind. & $7 / 11 / 2001$ & 1.70 & 7.42 & 7.91 & 722.0 & 27.00 & .27 & - \\
\hline 04100295 & Rimmell Branch near Albion, Ind. & $4 / 17 / 2002$ & - & 11.40 & 7.77 & 547.0 & 16.64 & ND & - \\
\hline 04098610 & Sherman Mill Creek at Sherman Mills Road near Sturgis, MI & $8 / 27 / 2002$ & - & - & - & - & - & 0.11 & .22 \\
\hline 041003747 & Solomon Creek at County Road 43 near Ligonier, IN & $8 / 27 / 2002$ & - & - & - & - & - & 0.08 & ND \\
\hline 04100377 & Solomon Creek near Syracuse, Ind. & $5 / 24 / 2001$ & 31.00 & 7.76 & 7.58 & 748.0 & 12.06 & .07 & - \\
\hline 04100377 & Solomon Creek near Syracuse, Ind. & $7 / 10 / 2001$ & 39.00 & 7.12 & 9.15 & 42.0 & 29.10 & .05 & - \\
\hline 04100377 & Solomon Creek near Syracuse, Ind. & $4 / 17 / 2002$ & 81.00 & 10.38 & 7.43 & 738.0 & 15.67 & ND & - \\
\hline 04100377 & Solomon Creek near Syracuse, Ind. & $8 / 14 / 2002$ & 8.80 & 9.21 & 6.68 & 719.0 & - & ND & - \\
\hline 04100303 & South Branch Elkhart River at River Road near Albion, IN & $8 / 27 / 2002$ & - & - & - & - & - & 0.405 & .49 \\
\hline 04096520 & South Branch Hog Creek at Boone Road near Quincy, MI & $8 / 29 / 2002$ & - & - & - & - & - & 0.26 & .13 \\
\hline 04096515 & South Branch Hog Creek near Allen, Mich. & $5 / 23 / 2001$ & 72.60 & 7.32 & 7.58 & 497.0 & 14.53 & 1.34 & - \\
\hline 04096515 & South Branch Hog Creek near Allen, Mich. & $7 / 13 / 2001$ & 9.60 & 7.42 & 6.73 & 569.0 & 18.16 & .50 & - \\
\hline 04096515 & South Branch Hog Creek near Allen, Mich. & $4 / 16 / 2002$ & 82.10 & 8.28 & 7.55 & 473.0 & 18.29 & .20 & - \\
\hline 04096515 & South Branch Hog Creek near Allen, Mich. & $8 / 14 / 2002$ & 5.65 & 8.70 & 7.88 & 570.0 & 22.84 & .08 & - \\
\hline 04096405 & St. Joseph River at Burlington, Mich. & $5 / 23 / 2001$ & 482.00 & 8.47 & 7.55 & 535.0 & 14.18 & 2.11 & - \\
\hline 04096405 & St. Joseph River at Burlington, Mich. & $7 / 13 / 2001$ & 93.40 & 8.67 & 7.61 & 268.0 & 19.60 & .19 & - \\
\hline 04096405 & St. Joseph River at Burlington, Mich. & $4 / 16 / 2002$ & 333.00 & 8.85 & 7.93 & 538.0 & 19.77 & ND & - \\
\hline 04096405 & St. Joseph River at Burlington, Mich. & $8 / 7 / 2002$ & 73.80 & 7.84 & 7.55 & 629.0 & 19.15 & .09 & - \\
\hline 04096405 & St. Joseph River at Burlington, Mich. & $8 / 14 / 2002$ & 60.40 & 7.76 & 7.40 & 9.0 & 21.79 & .06 & - \\
\hline 04101000 & St. Joseph River at Elkhart, IN & $8 / 28 / 2002$ & - & - & - & - & - & ND & .19 \\
\hline 04101000 & St. Joseph River at Elkhart, Ind. & $5 / 24 / 2001$ & 3880.00 & 8.00 & 7.90 & 527.0 & 17.53 & .78 & - \\
\hline 04101000 & St. Joseph River at Elkhart, Ind. & $7 / 10 / 2001$ & 1670.00 & 6.76 & 12.97 & 33.0 & 30.16 & .49 & - \\
\hline 04101000 & St. Joseph River at Elkhart, Ind. & $4 / 17 / 2002$ & 5800.00 & 9.81 & 8.03 & 536.0 & 19.19 & ND & - \\
\hline 04101000 & St. Joseph River at Elkhart, Ind. & $8 / 6 / 2002$ & 1430.00 & 7.54 & 7.89 & 604.0 & 25.75 & ND & - \\
\hline 04099000 & St. Joseph River at Mottville, Mich. & $5 / 22 / 2001$ & 2550.00 & 7.85 & 7.75 & 515.0 & 19.46 & 1.23 & - \\
\hline 04099000 & St. Joseph River at Mottville, Mich. & $7 / 12 / 2001$ & 793.00 & 6.64 & 7.01 & 481.0 & 25.46 & ND & - \\
\hline 04099000 & St. Joseph River at Mottville, Mich. & $4 / 16 / 2002$ & 3280.00 & 8.35 & 7.78 & 496.0 & 17.67 & ND & - \\
\hline 04099000 & St. Joseph River at Mottville, Mich. & $8 / 7 / 2002$ & 666.00 & 6.47 & 7.67 & 500.0 & 26.14 & .05 & - \\
\hline 04099000 & St. Joseph River at Mottville, Mich. & $8 / 18 / 2003$ & - & 8.21 & 7.83 & 499.7 & 26.48 & .09 & - \\
\hline 04101500 & St. Joseph River at Niles, MI & $8 / 28 / 2002$ & - & - & - & - & - & ND & .22 \\
\hline 04101500 & St. Joseph River at Niles, Mich. & $7 / 11 / 2001$ & 1910.00 & 7.58 & 6.84 & 214.0 & 24.26 & .28 & - \\
\hline 04101500 & St. Joseph River at Niles, Mich. & $4 / 15 / 2002$ & 6840.00 & 11.46 & 7.32 & 25.0 & 16.02 & .08 & - \\
\hline 04101500 & St. Joseph River at Niles, Mich. & $5 / 21 / 2002$ & 6840.00 & 9.12 & 7.92 & 585.0 & 20.49 & .58 & - \\
\hline 04101500 & St. Joseph River at Niles, Mich. & $8 / 6 / 2002$ & 1850.00 & 7.89 & 7.74 & 592.0 & 26.16 & ND & - \\
\hline 04101501 & St. Joseph River at Niles, Mich. (Auxiliary) & $8 / 18 / 2003$ & - & 7.61 & 8.02 & 596.0 & 25.82 & .35 & - \\
\hline 04097500 & St. Joseph River at Three Rivers, Mich. & $5 / 22 / 2001$ & 1960.00 & 8.19 & 7.82 & 509.0 & 19.02 & 1.60 & - \\
\hline 04097500 & St. Joseph River at Three Rivers, Mich. & $7 / 12 / 2001$ & 576.00 & 7.40 & 7.47 & 140.0 & 26.01 & ND & - \\
\hline 04097500 & St. Joseph River at Three Rivers, Mich. & $4 / 16 / 2002$ & 2560.00 & 9.62 & 8.04 & 470.0 & 19.13 & ND & - \\
\hline 04097500 & St. Joseph River at Three Rivers, Mich. & $8 / 7 / 2002$ & 491.00 & 6.71 & 7.17 & 460.0 & 24.16 & .08 & - \\
\hline 04096340 & St. Joseph River at Twenty-two Mile Road near Clarendon, MI & $8 / 30 / 2002$ & - & - & - & - & - & 0.18 & .12 \\
\hline
\end{tabular}




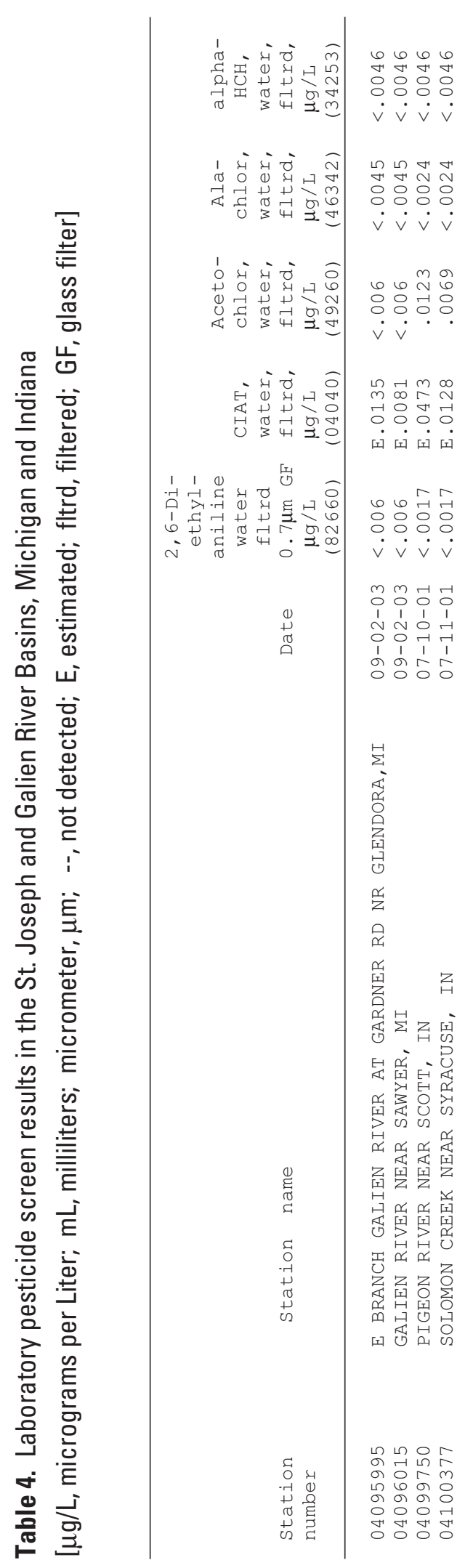

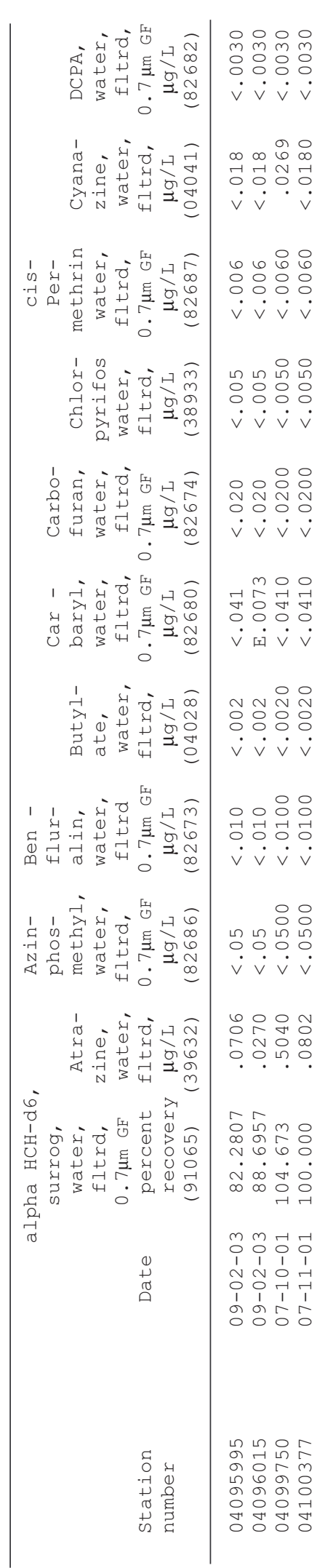

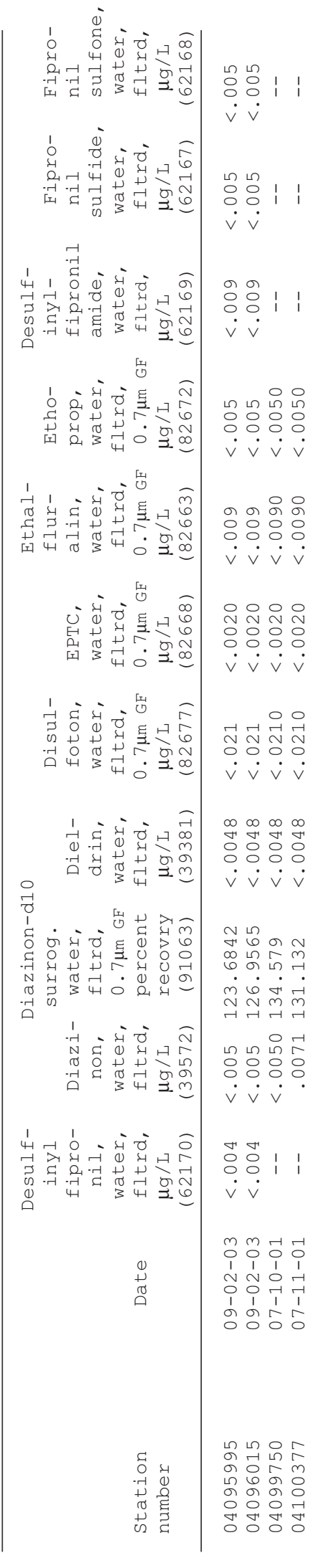




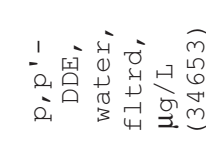

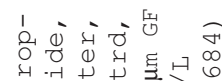

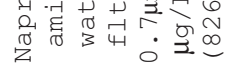

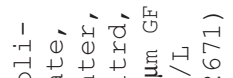

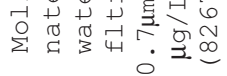

- $\begin{aligned} & -4 \\ & \text { दो }\end{aligned}$

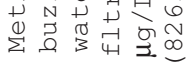

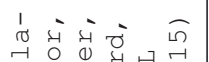

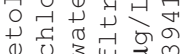

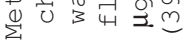

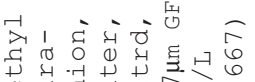

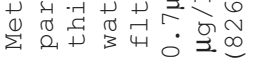

1. वें द्वे

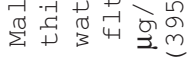

도웡

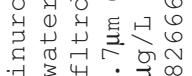

桨 $34: 00$

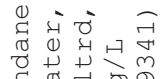

न्व

${ }_{0}^{20}$ iो

作

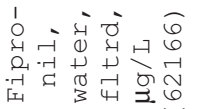

NㅜNNำ

$\dot{v} \dot{v} \dot{v} \dot{v}$

$\begin{array}{llll}r & r & 1 \\ 0 & 0 & 1 & 1 \\ 0 & 0 & 1 & 1\end{array}$

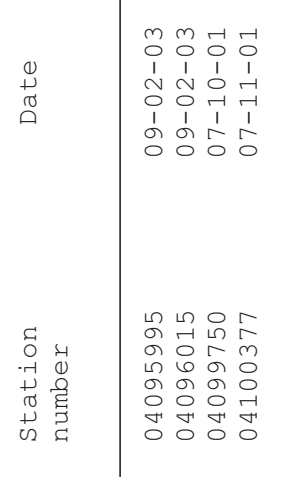

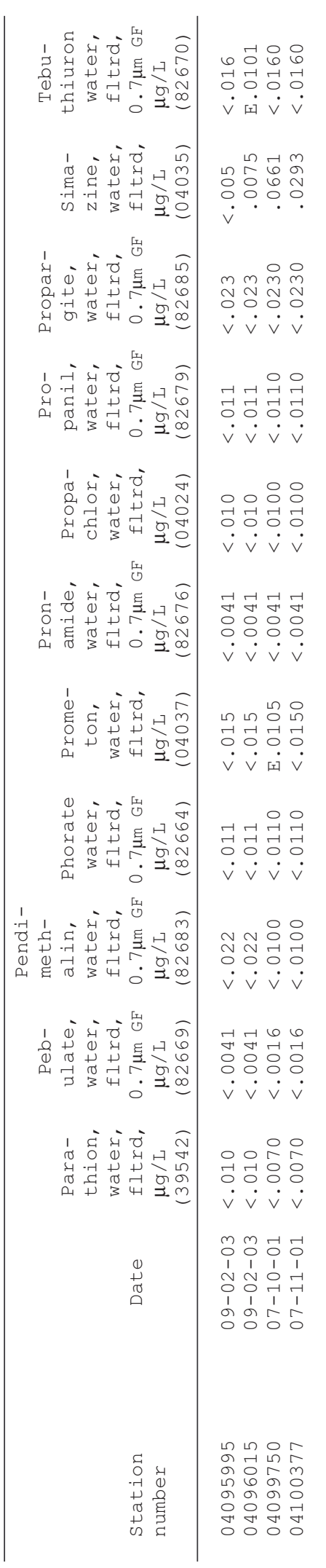

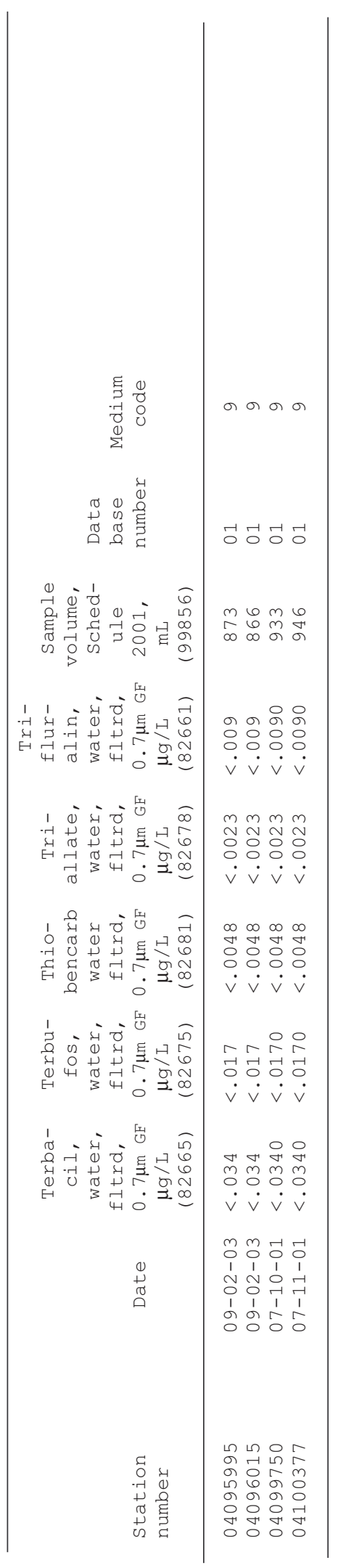




\section{Conclusions}

The purpose of this study was to determine whether atrazine was present in stream water within the two basins and whether local high atrazine concentrations could be identified as a first step in understanding the relation of ground water and surface water in atrazine transport. Spatial and temporal variations of atrazine concentrations were examined, as well as methodologies to investigate pore-water/stream-water interactions. This work was conducted in cooperation with the Michigan Department of Environmental Quality.

Atrazine was detected in stream-water and streambed pore-water samples from the St. Joseph and Galien River Basin from 2001-2003. Stream-water concentrations tended to peak in late spring when the herbicide was applied, and they decline to nondetection before the following spring planting. More work would be needed to relate agricultural management and herbicide application timetables, to observed atrazine concentrations in the St. Joseph and Galien River Basins.

No strong spatial relation between pore-water and stream-water atrazine concentrations was determined. Atrazine was detected in streambed sediment pore water at several sites across both basins, and the average of all pore-water atrazine concentrations was approximately equal to the average of all stream-water atrazine concentrations. However, the pattern of atrazine concentrations in the pore water and stream water suggested a potentially complex pore-water/stream-water relation that would require future studies to quantify.

To assess the precision of the field (ELISA) analyses, atrazine concentrations determined in 2001 and 2003 were verified by means of laboratory analysis. Some variation in these two analytical approaches is expected because the field atrazine screen also detects atrazine breakdown products; in most cases, the field-test concentrations were higher than the corresponding concentrations from the laboratory analysis. However, the presence of atrazine in field tests was verified by laboratory analysis in every comparison made.

The atrazine concentration at many sites (16 in May 2001; 9 in July 2001; 1 in April 2002; 3 in August 2002; 8 in September 2002 and 1 in August 2003) exceeded the concentration of atrazine that has been shown to feminize frog populations $(0.2 \mathrm{ppb})$.

\section{References}

Barbash, J.E. and Resek, E.A., 1996, Pesticides in ground water-distribution, trends, and governing factors: Chelsea, Mich., Ann Arbor Press, 588 p.

Blumer, S.P., Behrendt, T.E., Ellis, J.M., Minnerick, R.J., Leu Voy, R.L., and Whited, C.R., 2002, Water resources data, Michigan, water year 2001: U.S. Geological Survey Water-Data Report MI-01-1, 442 p.
Croley, T.E., II, Hunter, T.S., and Martin, S.K., 2001, Great Lakes monthly hydrologic data: Ann Arbor, Mich. NOAA Great Lakes Environmental Research Laboratory Technical Report \#TM-083, 13 p.

Hayes, T., Haston, K., Tsui, M., Hoang, A., Haeffele, C., and Vonk, A., 2002, Feminization of male frogs in the wild: Nature, v. 419, no. 6910, p. 895-896.

Holtschlag, D.J., and Nicholas, J.R., 1998, Indirect groundwater discharge to the Great Lakes: U.S. Geological Survey Open-File Report 98-579, 30 p.

Lindsey, B.D., Phillips S.W., Donnelly, C.A., Speiran, G.K., Plummer, L.N., Bohlke, J.K., Focazio, M.J., Burton, W.C., and Busenberg, E., 2003, Residence times and nitrate transport in ground-water discharging to streams in the Chesapeake Bay watershed: U.S. Geological Survey WaterResources Investigations Report 03-4035, 215 p.

Rantz, S.E., and others, 1982, Measurement and computation of streamflow: U.S. Geological Survey Water-Supply Paper $2175,631 \mathrm{p}$.

Renner, R., 2002, Conflict brewing over herbicide's link to frog deformities: Science, v. 298, no. 5595, p. 938-939.

Strategic Diagnostics Inc, 1999, RaPID assay atrazine test kit: Technical Report, A00002/A00071, Strategic Diagnostics Inc, $4 \mathrm{p}$.

U.S. Environmental Protection Agency, 2000a, National Primary Drinking Water Regulation-regulated contaminants: Title 40 Code of Federal Regulations, Part 141, Subpart 0, app. A, p. 336-538.

U.S. Environmental Protection Agency, 2000b, Lake Michigan Lake Wide Management Plan (LaMP 2000); accessed 1203-2004 at 10:15, http://www.epa.gov/glnpo/lakemich/

U.S. Geological Survey, 1992, National Land Cover Data Set.

U.S. Geological Survey, 1998, National Water Quality Assessment, Pesticide National Synthesis Project, annual use maps; accessed 12-03-04 at 15:30 http://ca.water.usgs. gov/pnsp/use92/index.htm

U.S. Geological Survey, 2000, A simple device for measuring differences in hydraulic head between surface water and shallow ground water: U.S. Geological Survey Fact Sheet FS-077-00, 2 p.

Webb, W.E., Radke, D.B., and Iwatsubo, R.T., eds., 1999, Surface-water sampling--collection methods at flowing-water and still-water sites: U.S. Geological Survey Techniques of Water-Resources Investigations, book 9, chap. 4.1, 32 p. 
Wilde, F.D., Radtke, D.B., Gibs, J., and Iwatsubo, R.T., eds., 1998, Cleaning of equipment for water sampling: U.S.

Geological Survey Techniques of Water-Resources Investigations, book 9, chapter A3, $81 \mathrm{p}$.

Zaugg, S.D., Sandstrom, M.W., Smith, S.G., and Fehlberg, K.M., 1995, Methods of analysis by the U.S. Geological Survey National Water Quality Laboratory-determination of pesticides in water by $\mathrm{C}-18$ solid-phase extraction and capillary-column gas chromatography/mass spectrometry with selected-ion monitoring: U.S. Geological Survey

Open-File Report 95-181, 6 p. 
心్ 